\title{
Review \\ Wee1 Kinase: A Potential Target to Overcome Tumor Resistance to Therapy
}

\author{
Francesca Esposito (D), Raffaella Giuffrida (D), Gabriele Raciti, Caterina Puglisi (D) and Stefano Forte *(D) \\ IOM Ricerca srl, Viagrande, I-95029 Catania, Italy; francesca.esposito@grupposamed.com (F.E.); \\ raffaella.giuffrida@grupposamed.com (R.G.); gabriele.raciti@grupposamed.com (G.R.); \\ caterina.puglisi@grupposamed.com (C.P.) \\ * Correspondence: stefano.forte@grupposamed.com
}

Citation: Esposito, F.; Giuffrida, R. Raciti, G.; Puglisi, C.; Forte, S. Wee1 Kinase: A Potential Target to Overcome Tumor Resistance to Therapy. Int. J. Mol. Sci. 2021, 22, 10689. https://doi.org/10.3390/ ijms221910689

Academic Editor: Valentina De Falco

Received: 8 September 2021

Accepted: 27 September 2021

Published: 1 October 2021

Publisher's Note: MDPI stays neutral with regard to jurisdictional claims in published maps and institutional affiliations.

Copyright: (c) 2021 by the authors. Licensee MDPI, Basel, Switzerland. This article is an open access article distributed under the terms and conditions of the Creative Commons Attribution (CC BY) license (https:// creativecommons.org/licenses/by/ $4.0 /)$.

\begin{abstract}
During the cell cycle, DNA suffers several lesions that need to be repaired prior to entry into mitosis to preserve genome integrity in daughter cells. Toward this aim, cells have developed complex enzymatic machinery, the so-called DNA damage response (DDR), which is able to repair DNA, temporarily stopping the cell cycle to provide more time to repair, or if the damage is too severe, inducing apoptosis. This DDR mechanism is considered the main source of resistance to DNA-damaging therapeutic treatments in oncology. Recently, cancer stem cells (CSCs), which are a small subset of tumor cells, were identified as tumor-initiating cells. CSCs possess self-renewal potential and persistent tumorigenic capacity, allowing for tumor re-growth and relapse. Compared with cancer cells, CSCs are more resistant to therapeutic treatments. Wee1 is the principal gatekeeper for both G2/M and S-phase checkpoints, where it plays a key role in cell cycle regulation and DNA damage repair. From this perspective, Wee1 inhibition might increase the effectiveness of DNA-damaging treatments, such as radiotherapy, forcing tumor cells and CSCs to enter into mitosis, even with damaged DNA, leading to mitotic catastrophe and subsequent cell death.
\end{abstract}

Keywords: Wee1 kinase; cell cycle; tumor resistance

\section{Introduction}

The cell cycle is a finely regulated process, where a series of growth and development steps alternate and several molecules are involved as negative or positive regulators. Proteins belonging to the highly evolutionarily conserved family, known as cyclin-dependent kinases (Cdks), interact with specific partner proteins named cyclins. The variation in cyclin protein levels is the mechanism through which cells progress through the cell cycle, alternating the phases that follow one another in a specific temporal sequence [1]. Besides the kinases, even their molecular counterparts, the phosphatases, take part in the cell cycle. Therefore, kinases and phosphatases alternatively regulate the same targets to allow for the correct conclusion of the process and to dynamically respond to the events.

The major events of the cell cycle are the S-phase, where the DNA replication occurs, and the M-phase, which finally leads to the generation of the two daughter cells. These phases are connected through "gap" steps (G1 and G2 respectively), during which, the cell prepares itself through modifications of its transcriptional activity to synthetize the molecules that are required for the following event.

Among the various steps, there are mechanisms of control, known as checkpoints, which temporarily stop the process when mistakes occur to avoid the transmission of mistakes that would compromise the result [2].

In normal cells, DNA damage is usually repaired via G1 phase arrest. In tumor cells, G1 checkpoint deficiencies can occur, especially in p53-deregulated cells. In these cells, the G2 checkpoint has the crucial role of repairing endogenous and exogenous DNA damage [3,4]. Consequently, targeting the effectors involved in the G2 checkpoint is a promising strategy for cancer therapy $[5,6]$. 
Wee1 belongs to a family of protein kinases that activate the G2/M checkpoint of the cell cycle in response to double-stranded DNA breaks (DDB) [7,8]. It is involved in the terminal phosphorylation and inactivation of Cdk1/Cdc2-bound cyclin B on its Tyr15 residue, resulting in cell cycle arrest at G2 and, therefore, a delayed entry into mitosis after DNA damage $[9,10]$.

\section{Wee1 Family}

Wee1 is one of the most important gatekeepers for both the G2/M checkpoint and S-phase. While its role in regulating the entry into mitosis is well known since its discovery, its involvement in the S-phase was discovered only recently. Since DNA synthesis and mitosis are tightly connected, when replication errors occur, the regulatory mechanism can slow down or temporarily stop the S-phase. This allows for DNA repair before the onset of mitosis, which will fix genetic mutations and/or chromosomal aberrations in the genome of daughter cells.

Wee1 belongs to a family of protein kinases, consisting of three members in humans, including PKMYT1 (membrane-associated tyrosine- and threonine-specific cdc2-inhibitory kinase) and two Wee1 kinases (Wee1 and Wee1B). They show sequence similarity on their kinase domain but differ regarding their localization, temporal expression and regulation.

Human Wee1, also known as Wee1A or Wee1Hu, is a kinase of 646 amino acids with a molecular weight of $94 \mathrm{kDa}$ comprising three domains: an N-terminal regulatory domain, a central kinase domain and a C-terminal regulatory domain $[9,11,12]$. The N-terminal domain is the longest and contains two phosphorylation sites (S53 and S123), which are involved in protein degradation through the proteasome. In fact, this domain presents three PEST (Pro-Glu-Ser-Thr) regions, which are found in many eukaryotic proteins and are characterized by a rapid turnover. A nuclear localization signal, which is in the same domain, is responsible for its subcellular localization (Figure 1).

Even if Wee1 acts as a tyrosine kinase, its catalytic domain is similar to the ones found on serine/threonine kinases rather than those found on tyrosine kinases. In fact, Wee1 acts on the Y15 residue on Cdk1-cyclin B. Its structural features suggest that Wee1 may have evolved from a serine/threonine kinase through mutations that somehow might have directed it to acquire the ability to phosphorylate tyrosine residues [12]. Finally, the C-terminal regulatory domain is very short and presents an S642, which constitutes a binding site for the chaperone 14-3-3.

Wee1B was identified for the first time in Xenopus oocytes. It shares with Wee1 its predominant nuclear localization and the ability to inactivate Cdk1-cyclin B through phosphorylation. However, higher levels of its mRNA were observed in mature oocytes with a marked decrease after fertilization, while Wee1 is more expressed in the zygotes. This suggests a different action during the early phase of embryogenesis, with Wee1B being more involved in the early steps and Wee1 in the latter steps [8].

While Wee1 and Wee1B are prevalently nuclear, PKMYT1 is not. Its C-terminal domain is anchored at the endoplasmic reticulum and Golgi apparatus; in addition, it binds Cdk1-cyclin B. Furthermore, it is a dual-specificity kinase and phosphorylates Cdk1-cyclin B in both Y15 and the adjacent threonine 14 [13,14]. PKMYT1 prevents cell entry in the M-phase in two ways: it maintains Cdk1-cyclin B inactivity and, at the same time, prevents the translocation of the complexes into the nucleus [15]. Moreover, it exhibits more restricted substrate specificity, acting on Cdk1 but only partially on Cdk2 [16].

The Wee1 gene, which is localized in the distal short arm of the human chromosome 11 [17], was first discovered in the fission yeast Schizosaccharomyces pombe. It is involved in the controlled onset of mitosis once the cell reaches the right size [18]. Moreover, a gene dosage effect was observed: several experiments on yeast indicated that Wee1 could delay progression through G2 into mitosis and this effect was more evident when its expression increased $[9,19]$. Orthologues of the yeast Wee1 gene were identified not only in human cells $[20,21]$ but in several other eukaryotes, such as mouse, chicken, lizard, zebrafish and the African clawed frog [22-28]. In addition to the above-mentioned members of the Wee1 
family, other paralog genes have been identified. They comprise four eukaryotic translation initiation factor genes (EIF2AK1, EIF2AK2, EIF2AK3, EIF2AK4), the serine/threonine kinase 35 (STK35) and the PDLIM1 interacting kinase 1 like (PDLIM1) genes.

A

Wee1

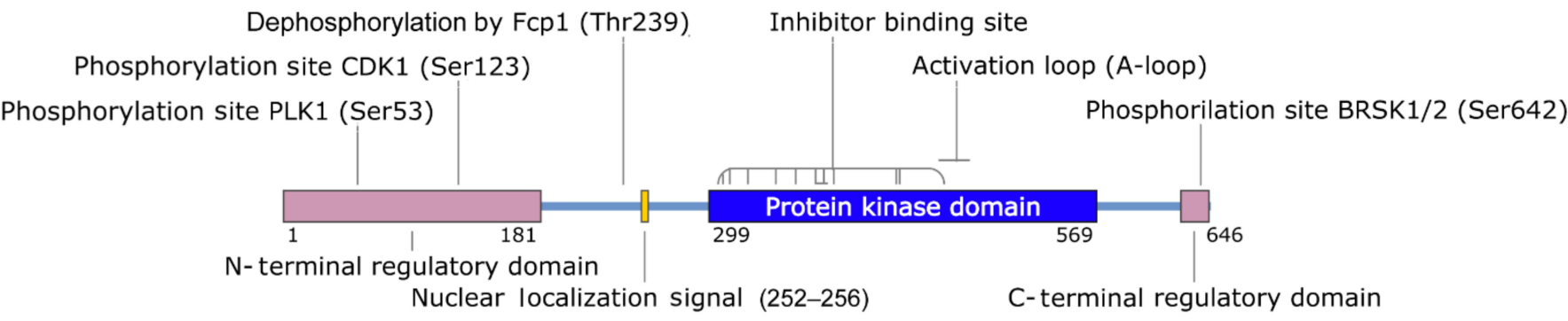

B

Wee1B

Ligand binding site (ATP)

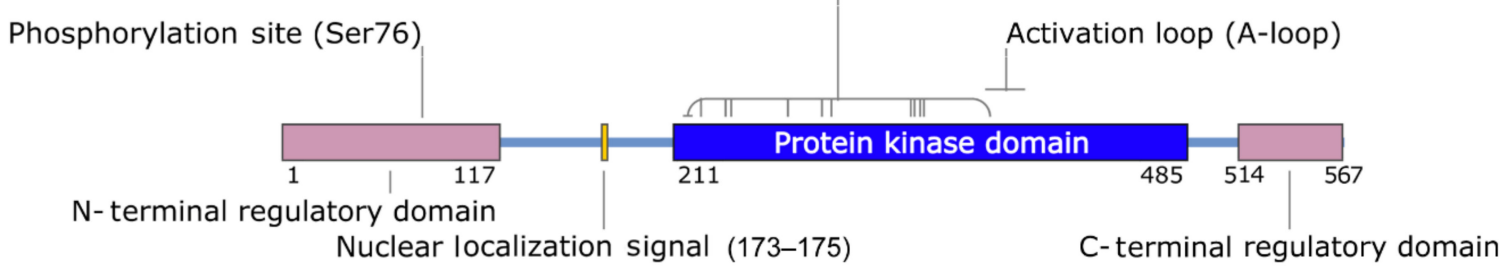

C

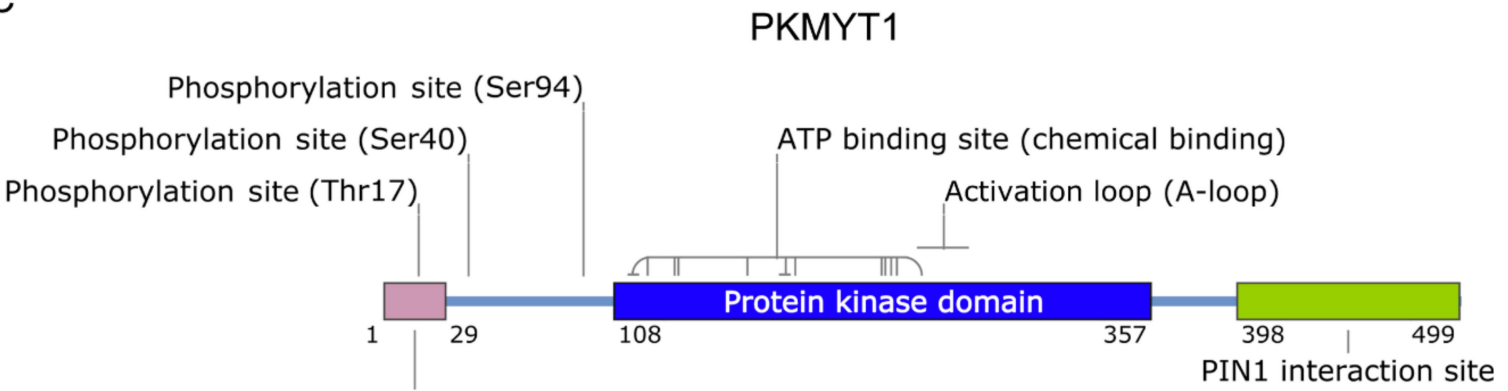

$\mathrm{N}$ - terminal regulatory domain

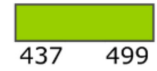

CDC2-CCNB1 interaction site

Figure 1. Schematic representation of Wee1 (A), Wee1B (B) and PKMYT1 (C) domain structures, interaction and posttranslational modifications sites.

Its activity is sustained by various molecules to acquire more stability, a prolonged half-life and, consequently, increased biochemical activity. In particular 14-3-3 proteins, which are molecular chaperones that interact with many proteins that are involved in signal transduction, are likely the most important [29]. Their binding during the interphase induces a conformational change at the N-terminal domain of Wee1, hiding its site for degradation. Consequently, Wee1 becomes more stable and thus enhances kinase activity. During mitosis, 14-3-3 instead loses its binding with Wee1, allowing for an easier inactivation [30-32].

Moreover, Hsp90 and MIG6 support Wee1 stability. Heat shock protein 90 (Hsp90), which is one of the most abundant and evolutionarily conserved chaperones, interacts with Wee1 and maintains it in its native conformation [32-35]. MIG6 is a known EGFR inhibitor whose expression is upregulated with cell growth. Sasaki and his collaborators recently identified a new EGFR-independent role in cell cycle progression. They demonstrated 
that MIG6 stabilizes Wee1, hindering the recruitment of $\beta$-TrCP-SCF and the subsequent proteasomal degradation [36].

\section{Wee1 in Cell Cycle Events}

Wee1 is predominantly localized in the nucleus, where it coordinates and ensures the proper DNA replication and, at the same time, prevents premature mitosis $[37,38]$.

Wee1 negatively regulates the G2/M transition that acts on the Cdk1-cyclin B complex (also known as mitosis promoting factor (MPF)), which, once activated, triggers all events leading to the onset of mitosis [39-41]. Wee1 phosphorylates Cdk1 (also known as cell division cycle 2 (Cdc2)) on the Y15 residue [21,42] within its ATP-binding site in the catalytic subunit, while PKMYT1 phosphorylates it on both the Y15 and T14 residues $[13,14,16]$. This phosphorylation inactivates Cdk1 during the interphase. Its activity is contrasted with Cdc25 phosphatases, whose levels change in a specular way compared to those of Wee1. Cdc25 dephosphorylates Y15 and T14 and, together with higher cyclin B levels, which promote the phosphorylation on its T161 residue by Cdk-activating kinase (CAK), activates Cdk1 $[43,44]$.

The downregulation of Wee1 promotes entry into mitosis. This is usually achieved via both decreased synthesis and proteolytic degradation [38]. When Wee1 is phosphorylated by Plk1 (polo-like kinase 1) and Cdk1 in S53 and S123, respectively, it becomes a target of the $\beta$-TrCP F-box protein-containing SCF E3 ubiquitin ligase (SCF $\beta$-TrCP) or Tome-1 F-box protein-containing SCF E3 ubiquitin ligase (SCFTome-1) complexes. Both $\beta-\operatorname{TrCP}$ and Tome-1 directly contribute to Wee1 inactivation [45-47]. Therefore, while phosphorylation does not directly inactivate Wee1, this event induces its proteasome-dependent degradation (Figure 2).

It is important to highlight that Wee1 inactivation is enhanced by Cdk1-cyclin B itself, which triggers a feedback loop: when Wee1 levels decrease, the balance between the tyrosine kinase and Cdk1-cyclin B complexes shifts toward the latter. These, in turn, phosphorylate Wee1, promoting its recognition for proteolytic degradation. Thus, the process ensures a rapid activation of Cdk1-cyclin B to allow for a quick transition to mitosis $[11,46]$.

During the S-phase, Wee1 acts on Cdk2 to stabilize the replication machinery, preventing unscheduled replication origins and the resulting insurgence of abnormal structures that might cause genomic instability [48]. The exact molecular mechanism is unclear: it could downregulate both Cdk2 and the Mus81-Eme1 endonuclease or Cdk1 and, only indirectly, Mus81-Eme1 activity $[49,50]$. In the presence of stalled forks, DSBs are induced by Mus81-Eme1 complexes to initiate recombination-mediated replication fork recovery. When downregulation that is caused by Wee1 is turned off, Cdk2 becomes hyperphosphorylated and thereby activates the Mus81-Eme1 endonuclease. Moreover, the phosphorylated form of $\mathrm{H} 2 \mathrm{~A}$ histone, namely, $\gamma-\mathrm{H} 2 \mathrm{AX}$, increases the formation foci that recruit molecules that are responsible for the DNA repair pathway. As such, the endonuclease binds to DNA, even in the absence of damage, and generates DSBs, cleaving the DNA in an unscheduled manner, thus reducing replication fork speed $[49,51]$. Therefore, Wee1 activity stabilizes those replication forks, which are temporarily stalled without becoming a signal to activate the DNA damage response.

Furthermore, Wee1 prevents the multiple and unscheduled activation of replication forks, leading, in turn, to the rapid consumption of the deoxynucleotide triphosphates (dNTPs) pool. Therefore, more replication forks become stalled and S-phase arrest ensues $[52,53]$.

Recently, Vassilopoulos et al. found a novel interaction between Wee1 and anaphasepromoting complex/cyclosome (APC/C). Activated APC/C is an E3 ubiquitin ligase that targets key proteins, including cyclin B and securin, causing them to degrade, thus promoting anaphase initiation and segregation of sister chromatids. In the presence of DNA damage in the S-phase, Wee1 phosphorylates APC/C, which, as a result, becomes inactive. 
If Wee1 is inactivated, APC/C recruits polo-like kinase 1 (Plk-1), which degrades Wee1, and the cell cycle proceeds independently due to the integrity of the genetic information [54].

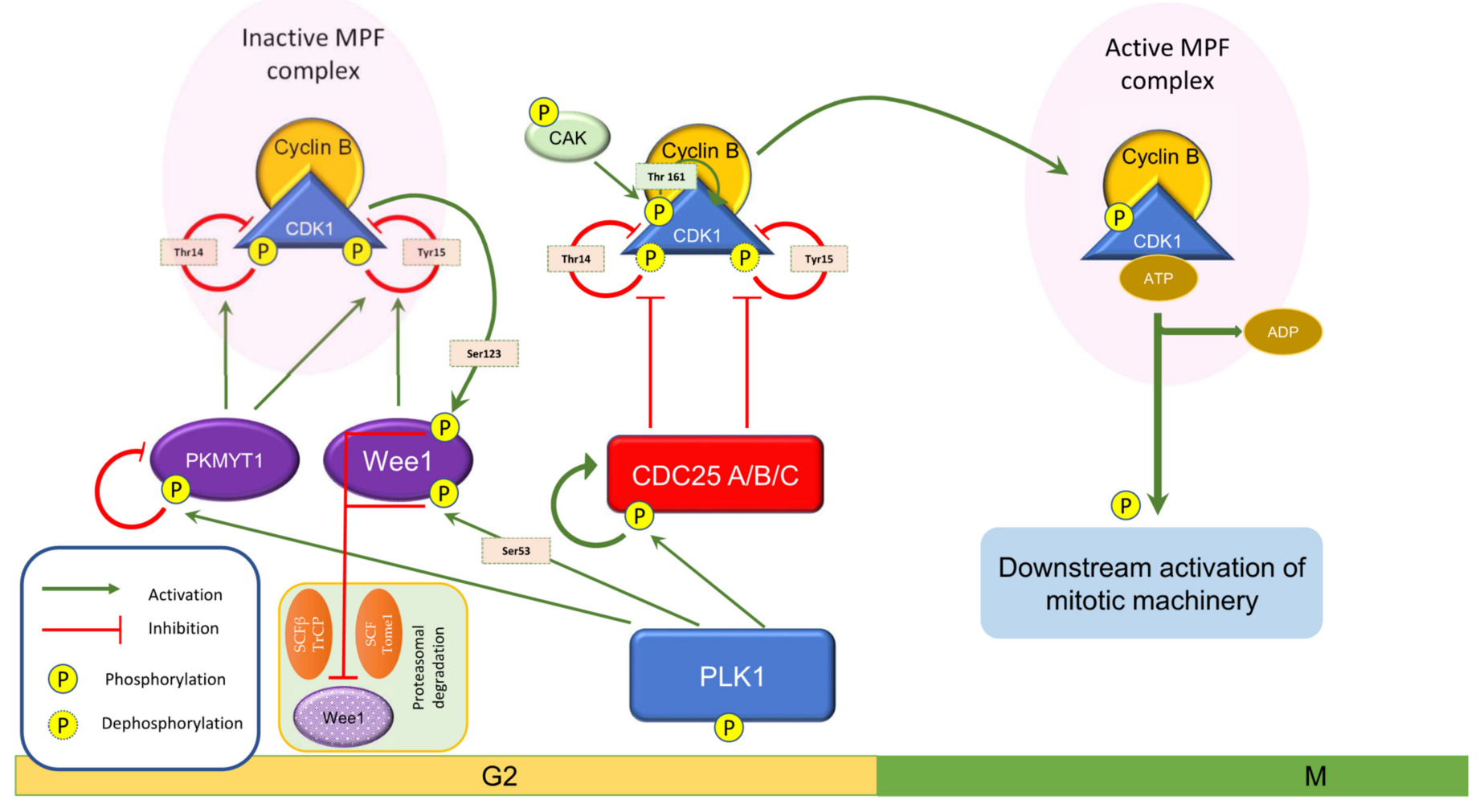

Figure 2. Schematic representation of the components involved in G2/M cell cycle transition.

Finally, Wee1 can act as an epigenetic modifier: in the late S-phase, when DNA synthesis is completed, it phosphorylates $\mathrm{H} 2 \mathrm{~B}$ histone at the Y37 residue, suppressing the transcription of Hist1, which is the major histone gene cluster. Thus, by modifying the chromatin structure, histone overproduction is avoided. This is an evolutionarily conserved process in the eukaryotic cells, as it is observed in yeast and mammals [55].

To better understand the role of Wee1 in mammalian tissue, in 2006, the group of Prof. Deng produced Wee1 knockout mice via gene targeting, which resulted in embryonic lethality at the blastocyst stage [56], which explained the lack of in vivo models. In 2015, the same group established conditional and tissue-specific Wee1 mutant mice and cells. Alongside the well-known role of Wee1 in preventing premature mitotic entry, Wee1 mutant cells revealed impaired mitosis that was characterized by delayed progression and completion without normal cytokinesis. Moreover, they found a role of Wee1 in modulating the APC/C complex, i.e., it is responsible for the degradation of mitotic regulator protein by a proteasome. Thus, Wee1 deficiency causes increased activity of APC/C, which allows for mutant cells to progress through mitosis at the expense of genomic integrity. Finally, in the animal model with a conditional expression of Wee1 in the mammary gland, they demonstrated that Wee1 is indispensable for maintaining genomic stability and it acts as a haploid tumor suppressor since a mutant mammary gland develops tumors. In conclusion, Wee1 coordinates distinct cell-division events to permit correct segregation of genetic information into daughter cells and preservation of genomic integrity [54].

\section{Role of Wee1 Kinase in Cancer Progression and Therapy}

The expression of Wee1 was investigated in few studies, including solid tumors and hematological malignancies. Wee1 downregulation in cancer tissues was observed in most of them, suggesting a tumor suppressor role for Wee1. In stromal breast cancer, Wee1 
expression was investigated using immunohistochemistry. The lower Wee1 expression in malignant tumors compared to benign ones suggests that it acts as a tumor suppressor [57]. Similarly, a cDNA array performed on colon carcinoma cell lines and human tissues showed low Wee1 mRNA expression, leading to the speculation that genetic lesions targeting cell cycle regulation occur not only at the G1-S but also the G2-M transition checkpoint during tumor development [58]. Since the Wee1-mediated inhibition of G2-M transition is an essential step after DNA damage, permitting DNA repair prior to entry into mitosis [37], the decreased expression or loss of the Wee1 gene in colon carcinoma cells suggests its potential role as a tumor suppressor [58]. The association between Wee1 downmodulation and tumorigenesis was also found in non-small-cell lung cancer (NSCLC) [59]. In this work, the authors found a correlation between low Wee1 levels and a poor prognosis, as impaired Wee1 expression provided an advantage to neoplastic cells since it caused a faster progression through the cell cycle [59]. In their work, Yoshida et al. investigated the clinicopathological and prognostic significance of cyclin B and Wee1 expressions in 79 patients affected by NSCLC. It was found that in almost two-thirds of patients analyzed, Wee1 was not expressed and the patients had a poorer prognosis and a higher recurrence rate. Moreover, their tumors tended to have a higher Ki index and PCNA-LI values, which are typical parameters of cell proliferation and malignancy potential in NSCLC. Taken together, these data suggested that a loss of Wee1 expression may both promote tumor aggressiveness and be a useful prognostic indicator.

Few studies have evaluated the role of microRNAs (miRNAs), long non-coding RNAs (lncRNAs) and small-interference RNAs (siRNAs) that are able to modulate Wee1 expression in tumor cells and their involvement in tumor progression [60-64]. Aside from the evidence of an inverse correlation between Wee1 protein expression and the aggressiveness of melanoma cells, Bhattacharya et al. found a link with miR-195. They demonstrated that miR-195 has an inhibitory activity on Wee1 expression in melanoma metastases [61]. Data that was obtained by assessing cell cycle analyses during simultaneous Wee1 silencing (by siRNA or miR-195) and genotoxic agents' exposure suggested that when chemotherapymediated DNA damage occurs, miR-195 is able to significantly contrast the G2/M cell cycle arrest, downmodulating Wee1 in melanoma cells. [61]. In contrast, the upregulation of miR-101-3p via lncRNA NEAT1_2 in hepatocellular carcinoma cells decreased both the mRNA and protein levels of Wee1, inducing tumor radio-sensitization [60]. Comparable results were obtained in myeloid leukemia cell lines, whose Wee1 siRNA silencing resulted in a strong sensitization to cytarabine (Ara-C) [65]. While these data indicate that Wee1 acts as a tumor suppressor, several studies highlighted an increased expression of Wee1 in several types of cancer. This indicates that Wee1 may be important for cancer cells' viability under specific circumstances. A cell viability assessment with a kinase siRNA library in different cancer cell lines demonstrated that Wee1 gene expression correlated with the Wee1 gene copy number, potentially identifying a cause of increased expression [66]. Moreover, this study demonstrated that tumor cell lines that overexpress Wee1 are more sensitive to Wee1 inhibition by siRNA, leading to abrogation of the G2/M checkpoint and consequent tumor cell death via apoptosis. In particular, thanks to this approach, authors could identify a breast cancer patient subset (luminal breast cancer) that overexpressed Wee1, where its inhibition could be suggested as a potential therapeutic strategy [66]. Interestingly, by performing a stringent in silico analysis on data obtained comparing normal versus cancer tissue, Mir et al. found increased expression of Wee1 in most cancer types (27 samples in a 35-sample data set) [67]. In their dataset, the highest Wee1 mRNA expression was measured in glioblastoma, followed by non-small-cell lung carcinoma, (non-)seminoma and colon carcinoma, whereas the other cancer types mostly showed moderate overexpression as compared to the relevant non-neoplastic control tissue [67].

The activity of Wee1 was found to be increased in patients with advanced hepatocellular carcinoma when compared with noncancerous liver tissue [68]. Moreover, Wee1 was found to be overexpressed and functionally important in medulloblastoma [69], and a high expression of Wee1 was described in glioma [70,71]. Slipicevic et al. reported an 
expression of Wee1 in ovarian serous carcinoma effusions. Moreover, they observed a notable increase in Wee1 levels after exposure to chemotherapy, suggesting a role for this kinase in mediating the progression of the disease. Thus, increased Wee1 expression may represent an adaptive response to the chemotherapy that allows tumor cells to repair DNA damage and thereby survive [72].

Although Wee1 expression was found to increase in vulvar squamous cell carcinomas compared to normal tissue, Magnussen et al. did not observe any significant association between disease-specific survival and Wee1 expression in patients with vulvar carcinomas [73]. These findings did not directly support the tumor suppressor role of Wee1. Moreover, Wee1 silencing by siRNA did not translate to any major alteration in viability [73]. However, in their previous study, Magnussen and colleagues linked the expression of Wee1 with the activation of cellular pathways that are crucial for the specific disease [74]. In nasopharyngeal (NP) carcinoma cell lines, Wee1 was found to be overexpressed and, consequently, cells were found to be more sensitive to its inhibition compared to NP epithelial cells, although such inhibition was not very effective in sensitizing cells to radiotherapy [75]. In melanoma cells, Wee1 overexpression showed a strong, positive correlation with markers of proliferation: cyclin A, Ki67 and cyclin D3 [74]. Wee1 silencing caused an increase in phospho p38 protein levels, indicating a role in the regulation of p38/MAPK pathway activation during p53-independent DNA damage responses [74].

Aside from the reported use of siRNA for the inhibition of Wee1 expression in different cancer models, several pharmacological inhibitors were developed and validated, both as single agents or in combination with DNA damaging agents (chemotherapy/radiotherapy) [69,76-79]. Wee1 kinase inhibition causes a significant reduction in phospho- CDK1 (Tyr15), thus promoting the accumulation of the active CDK1-cyclin B1 complex and driving premature mitotic entry. Uncontrolled and deregulated mitosis is associated with a progressive DNA damage accumulation, culminating in cell death through a mechanism that is generally known as a mitotic catastrophe. The efficacy of Wee1 inhibitors as monotherapy was confirmed by a decrease in cell viability of ovarian cancer and sarcoma cell lines [80,81].

A large number of studies demonstrated that the cellular rate of response to treatment with Wee1 inhibitors or mimics was strictly dependent on a concomitant (i) presence of TP53 mutations [82-84] and/or (ii) administration of DNA-damaging agents (chemotherapy including doxorubicin, cytarabine, methotrexate, cisplatin, clofarabine, etoposide, 5 -fluorouracil and radiotherapy) [85,86]. Moreover, some data suggest that cells with dysfunctional p53 are more sensitive to Wee1 inhibition combined with conventional chemotherapy than those with functional p53. A possible explanation for this is that the dysfunctional G1/S DNA damage checkpoint yields TP53-mutated cells that are more dependent on stopping in $\mathrm{G} 2$ to repair DNA damage before entering mitosis.

While some studies described ionizing radiation (IR) [87,88] and chemotherapy [89] sensitization mediated by Wee1 inhibition to be dependent on TP53 activity, the pharmacological inhibition of Wee1, in combination with cytarabine, was shown to be effective in AML cell lines with functional p53 [90]. Van Linden demonstrated that the functionality of p53 does not influence the sensitization to antimetabolite chemotherapeutics by Wee1 inhibitors in AML cells and lung cancer cells, suggesting that the use of p53 mutation as a predictive biomarker for response to Wee1 inhibition may be restricted to certain cancers and/or chemotherapeutics, as well as the preclinical data supporting the combination [91].

Table 1 summarizes the above reported evidence observed in different cancer types. 
Table 1. Bibliographic evidence about Wee1 expression in different cancer types.

\begin{tabular}{|c|c|c|c|c|c|}
\hline Wee1 Expression & $\begin{array}{c}\text { Other } \\
\text { Molecular } \\
\text { Modulation }\end{array}$ & Cancer Type & Clinical Significance & Methods & Ref. \\
\hline$\downarrow$ Wee1 & & $\begin{array}{l}\text { Stromal breast } \\
\text { cancer (phyllodes } \\
\text { tumor (PT)) } \\
\text { human tissue } \\
\text { samples }\end{array}$ & $\begin{array}{l}\text { Wee } 1 \text { reduction suggests a } \\
\text { potential role of Wee } 1 \text { as a } \\
\text { tumor suppressor }\end{array}$ & Immunohistochemistry & [57] \\
\hline$\downarrow$ Wee1 & & $\begin{array}{l}\text { Colon carcinoma } \\
\text { cell lines and } \\
\text { human tissue } \\
\text { samples }\end{array}$ & $\begin{array}{l}\text { Wee1 suppression } \\
\text { suggests a potential role of } \\
\text { Wee1 in tumorigenesis }\end{array}$ & $\begin{array}{l}\text { cDNA array, Northern } \\
\text { blotting and } \\
\text { semi-quantitative } \\
\text { reverse } \\
\text { transcription-PCR } \\
\text { (RT-PCR) }\end{array}$ & [58] \\
\hline$\downarrow$ Wee1 & $\begin{array}{c}\uparrow \text { Cyclin B1/cdc2 } \\
\text { complex }\end{array}$ & $\begin{array}{l}\text { NSCLC human } \\
\text { tissue samples }\end{array}$ & $\begin{array}{l}\text { Wee1 reduction is } \\
\text { associated with a poorer } \\
\text { prognosis and a higher } \\
\text { recurrence rate }\end{array}$ & Immunohistochemistry & [59] \\
\hline$\downarrow$ Wee1 & $\uparrow \mathrm{miR}-195$ & $\begin{array}{c}\text { Metastatic } \\
\text { melanoma cell } \\
\text { lines and human } \\
\text { tissue samples }\end{array}$ & $\begin{array}{c}\text { Wee1 expression in } \\
\text { malignant melanoma is } \\
\text { directly regulated by } \\
\text { miR-195 }\end{array}$ & $\begin{array}{l}\text { Immunoblotting, } \\
\text { quantitative real-time } \\
\text { PCR and immunohis- } \\
\text { tochemistry }\end{array}$ & [61] \\
\hline$\uparrow$ Wee1 & $\downarrow$ miR-101-3p & $\begin{array}{l}\text { Hepatocellular } \\
\text { carcinoma (HCC) } \\
\text { cell lines and } \\
\text { human tissue } \\
\text { samples }\end{array}$ & $\begin{array}{l}\text { Downregulation of Wee1 } \\
\text { enhances the } \\
\text { radiosensitivity of HCC } \\
\text { cells }\end{array}$ & $\begin{array}{l}\text { Quantitative real-time } \\
\text { PCR, Western blotting } \\
\text { and flowcytometry }\end{array}$ & [60] \\
\hline$\uparrow$ Wee1 & & Leukemia cell lines & $\begin{array}{l}\text { Wee1 kinase inhibition by } \\
\text { siRNA silencing or by } \\
\text { specific inhibitors potently } \\
\text { sensitizes myeloid and } \\
\text { lymphoid leukemia cells } \\
\text { to Ara-C }\end{array}$ & $\begin{array}{l}\text { High-throughput } \\
\text { siRNA screen and } \\
\text { Western blotting }\end{array}$ & [65] \\
\hline$\uparrow$ Wee1 & & $\begin{array}{l}\text { Luminal breast } \\
\text { cancer cell lines }\end{array}$ & $\begin{array}{l}\text { Wee1 kinase inhibition by } \\
\text { specific inhibitors has } \\
\text { therapeutic potentials }\end{array}$ & $\begin{array}{l}\text { High-throughput } \\
\text { siRNA screen, Western } \\
\text { blotting and immuno- } \\
\text { histochemistry }\end{array}$ & [66] \\
\hline$\uparrow$ Wee1 & & $\begin{array}{l}\text { Nasopharyngeal } \\
\text { carcinoma (NPC) } \\
\text { cell lines }\end{array}$ & $\begin{array}{l}\text { Wee1 kinase inhibition by } \\
\text { specific inhibitors has } \\
\text { therapeutic potentials }\end{array}$ & Western blotting & [75] \\
\hline$\uparrow$ Wee1 & & $\begin{array}{l}\text { Glioblastoma cell } \\
\text { lines and human } \\
\text { tissue samples }\end{array}$ & $\begin{array}{c}\text { Wee1 kinase inhibition by } \\
\text { siRNA or specific } \\
\text { inhibitors causes cell } \\
\text { death and sensitizes } \\
\text { glioblastoma to ionizing } \\
\text { radiation in vivo, } \\
\text { suggesting it has a } \\
\text { potential therapeutic } \\
\text { target }\end{array}$ & $\begin{array}{l}\text { In silico analysis of } \\
\text { microarray data, } \\
\text { immunofluorescence } \\
\text { staining, immunohisto- } \\
\text { chemistry and Western } \\
\text { blotting }\end{array}$ & [67] \\
\hline $\begin{array}{c}\uparrow \text { Wee1 kinase } \\
\text { activity }\end{array}$ & $\uparrow$ Cyclin D1 & $\begin{array}{l}\text { Hepatocellular } \\
\text { carcinoma }(\mathrm{HCC}) \\
\text { human tissue } \\
\text { samples }\end{array}$ & $\begin{array}{l}\text { Activation of cyclin D1, } \\
\text { Cdk4, cyclin E, cyclin A } \\
\text { and Wee1 may play } \\
\text { important roles in the } \\
\text { process of malignant } \\
\text { transformation of cirrhosis } \\
\text { to HCC }\end{array}$ & $\begin{array}{c}\text { Evaluation of WEE1 } \\
\text { kinase activity using } \\
\text { autoradiography }\end{array}$ & [68] \\
\hline
\end{tabular}


Table 1. Cont.

\begin{tabular}{|c|c|c|c|c|c|}
\hline Wee1 Expression & $\begin{array}{c}\text { Other } \\
\text { Molecular } \\
\text { Modulation }\end{array}$ & Cancer Type & Clinical Significance & Methods & Ref. \\
\hline$\uparrow$ Wee1 & & $\begin{array}{l}\text { Medulloblastoma } \\
\text { cell lines and } \\
\text { human tissue } \\
\text { samples }\end{array}$ & $\begin{array}{l}\text { Wee1 kinase inhibition by } \\
\text { siRNA or specific } \\
\text { inhibitors (MK-1775) } \\
\text { potently inhibits tumor } \\
\text { growth in vivo and } \\
\text { sensitizes } \\
\text { medulloblastoma cells to } \\
\text { cisplatin in vitro, } \\
\text { suggesting Wee1 as a } \\
\text { potential therapeutic } \\
\text { target }\end{array}$ & $\begin{array}{l}\text { Gene expression } \\
\text { analysis, } \\
\text { high-throughput } \\
\text { siRNA screen and } \\
\text { Western blotting }\end{array}$ & [69] \\
\hline$\uparrow$ Wee1 & & $\begin{array}{l}\text { Glioma human } \\
\text { tissue samples }\end{array}$ & $\begin{array}{l}\text { Wee1 expression is } \\
\text { directly correlated with } \\
\text { the malignancy grade in } \\
\text { all types of gliomas, but it } \\
\text { is inversely associated } \\
\text { with prognosis in GBM }\end{array}$ & Immunohistochemistry & [71] \\
\hline$\uparrow$ Wee1 & & $\begin{array}{c}\text { Pediatric } \\
\text { high-grade glioma }\end{array}$ & $\begin{array}{l}\text { Wee1 expression } \\
\text { positively correlates with } \\
\text { the glioma grade; the } \\
\text { Wee1 inhibitor MK-1775 } \\
\text { increases the radiation } \\
\text { cytotoxic effect and } \\
\text { prolongs survival for mice } \\
\text { with engrafted, orthotopic } \\
\text { glioma }\end{array}$ & $\begin{array}{l}\text { Gene expression } \\
\text { analysis and immuno- } \\
\text { histochemistry }\end{array}$ & [70] \\
\hline$\uparrow$ Wee1 & & $\begin{array}{l}\text { Melanoma cell } \\
\text { lines and human } \\
\text { tissue samples }\end{array}$ & $\begin{array}{l}\text { High expression of WEE1 } \\
\text { is associated with poor } \\
\text { prognosis and Wee1 } \\
\text { silencing increases tumor } \\
\text { cell death; Wee1 } \\
\text { represents a potential } \\
\text { therapeutic target in } \\
\text { melanoma }\end{array}$ & $\begin{array}{l}\text { Immunohistochemistry } \\
\text { and Western blotting }\end{array}$ & [74] \\
\hline$\uparrow$ Wee1 & & $\begin{array}{l}\text { Vulvar squamous } \\
\text { cell carcinomas } \\
\text { human tissue } \\
\text { samples }\end{array}$ & $\begin{array}{l}\text { High Wee1 expression is } \\
\text { associated with poor } \\
\text { histological differentiation } \\
\text { and lymph node } \\
\text { metastases }\end{array}$ & $\begin{array}{l}\text { Immunohistochemistry } \\
\text { and } \\
\text { Wee1 silencing using } \\
\text { siRNA }\end{array}$ & [73] \\
\hline$\uparrow$ Wee1 & & $\begin{array}{l}\text { Acute myeloid } \\
\text { leukemia (AML) } \\
\text { cell lines and AML } \\
\text { primary cells }\end{array}$ & $\begin{array}{l}\text { Wee1 inhibition sensitizes } \\
\text { AML cells to cytarabine } \\
\text { in vitro; Wee1 represents a } \\
\text { potential therapeutic } \\
\text { target in AML }\end{array}$ & $\begin{array}{c}\text { Integrated genomic } \\
\text { analyses }\end{array}$ & [90] \\
\hline$\uparrow$ Wee1 & & $\begin{array}{l}\text { Osteosarcoma cell } \\
\text { lines, human } \\
\text { osteoblasts and } \\
\text { tumor samples }\end{array}$ & $\begin{array}{c}\text { Wee1 inhibition } \\
\text { sensitizing OS cells to } \\
\text { irradiation-induced cell } \\
\text { death }\end{array}$ & $\begin{array}{l}\text { Gene-expression data } \\
\text { analysis, immunohisto- } \\
\text { chemistry and Western } \\
\text { blotting }\end{array}$ & [86] \\
\hline
\end{tabular}


Table 1. Cont.

\begin{tabular}{|c|c|c|c|c|c|}
\hline Wee1 Expression & $\begin{array}{c}\text { Other } \\
\text { Molecular } \\
\text { Modulation }\end{array}$ & Cancer Type & Clinical Significance & Methods & Ref. \\
\hline$\uparrow$ Wee1 & & $\begin{array}{l}\text { Multiple myeloma } \\
\text { (MM) tissue } \\
\text { samples and cell } \\
\text { lines }\end{array}$ & $\begin{array}{l}\text { Wee1 inhibition in } \\
\text { combination with } \\
\text { Bortezomib induces cell } \\
\text { death in all cell lines more } \\
\text { efficiently compared to the } \\
\text { single agents }\end{array}$ & $\begin{array}{l}\text { Quantitative real-time } \\
\text { PCR (qPCR) }\end{array}$ & [89] \\
\hline$\uparrow$ Wee1 & & $\begin{array}{l}\text { Ovarian carcinoma } \\
\text { (OC) peritoneal } \\
\text { effusion samples } \\
\text { and cell lines }\end{array}$ & $\begin{array}{l}\text { Wee1 is overexpressed in } \\
\text { post-chemotherapy } \\
\text { disease, suggesting a role } \\
\text { in mediating disease } \\
\text { progression and as a } \\
\text { prognostic marker of poor } \\
\text { survival; Wee1 is a } \\
\text { potential therapeutic } \\
\text { target in OC }\end{array}$ & $\begin{array}{l}\text { Immunohistochemistry } \\
\text { and Western blotting }\end{array}$ & [72] \\
\hline
\end{tabular}

\section{Radiotherapy and DNA Damage Response (DDR)}

Radiation therapy is one of the crucial cancer treatment options along with surgery and chemotherapy [92]. The curative potential of radiotherapy depends on the amount of non-repairable DNA lesions that occurred in the exposed tumor tissue, thereby removing cancer cells from the clonogenic pool [93-96].

DNA integrity can be compromised by several types of exogenous and/or endogenous injuries. In particular, exposure to ionizing radiation is responsible for base and sugar damage, cross-links and both single- and double-strand breaks (SSBs and DSBs, respectively). Among these, DNA double-strand breaks (DSBs) principally contribute to radiation-induced cell death. However, cells can avoid this fate through DNA repair mechanisms. When DNA damage occurs, cells can arrest cycle progression to allow for DNA repair before cell division, which makes DNA alteration permanent. In fact, the accumulation of DNA lesions may lead to cell death and/or senescence if the damage is too severe to be repaired [97].

DNA repair mechanisms are the key determinant of tumor cell sensitivity (or resistance) to radiation and, for this reason, have gained a lot of interest in the oncology field. If the DNA repair capacity of tumor cells is not able to mitigate the severity of radiationinduced DSBs, this might result in the perpetuation of DNA damage, leading to irreparable genetic lesions that culminate in cell death. In contrast, if cells can repair radiation-induced damage, cancer cells continue to proliferate and tumors may recur [98].

In the presence of genotoxic stress, three different DNA damage repair (DDR) pathways are activated. Three phosphatidyl inositol 3-kinase-related protein kinases are the upstream molecules involved, though activated by different injury types. Ataxia telangiectasia mutated (ATM) responds to DNA-damage agents, such as IR, causing DSBs. Ataxia telangiectasia and Rad3-related (ATR) kinase detect alterations of replications (stalled replication forks and branched structures formation) that occur naturally or after ultraviolet light (UV) exposure. Like ATM, the DNA-dependent protein kinase (DNA-PK) signaling pathway is activated by DSBs under different cellular conditions, including IR exposure, environmental carcinogens and chemotherapeutic agents, or in cells with shortened telomeres.

ATM is recruited to DSBs by the Mre11-Rad50-Nbs1 (MRN) complex, whereas DNA-PK is recruited by the Ku70/Ku80 heterodimer [99]. ATR is recruited by the ATR-interacting protein (ATRIP) to replication protein A (RPA)-coated single-stranded DNA (ssDNA), which forms at stalled DNA replication forks or is generated by processing 
of the initial DNA damage [100-102]. Both ATM and ATR are able to induce chromatin modification in the presence of DNA damage through phosphorylation of $\mathrm{H} 2 \mathrm{AX}$, forming foci at the break sites. H2AX, once phosphorylated (creating $\gamma-\mathrm{H} 2 \mathrm{AX}$ ), allows for the recruitment of other proteins that take part in the repair mechanism [103]. ATM and ATR regulate the Werner syndrome protein (WRN), which is implicated in the recovery of stalled replication forks, to limit fork collapse [104] and act on BRCA-1, which serves as a scaffold to facilitate ATM and ATR to activate downstream substrates [105].

When recruited, ATM and ATR phosphorylate several substrates. Their principal downstream effectors are two kinases, namely, Chk2 and Chk1, which spread the signal to other molecules [106,107].

Chk2 acts on protein p53, which is the principal gatekeeper of the G1-phase, determining the arrest of the cell cycle. ATM can also directly regulate p53 stability, weakening its interaction with its negative regulator, namely, the MDM2 oncoprotein, whose gene is, in turn, activated by p53 itself [108].

Among Chk1 substrates, in addition to Wee1, whose function as the gatekeeper in G2/M checkpoint and S-phase was discussed above, there are the phosphatases Cdc25 (A, $\mathrm{B}$ and $\mathrm{C}$ ). Their activities are directly inhibited, promoting their degradation and causing cell cycle delay not only in the G2/M checkpoint but even in other steps, providing time for DNA repair [109,110]. However, Chk1 regulates Cdc25 levels both in the presence of DNA damage and in physiological conditions, supporting its rapid turnover and avoiding an unscheduled massive DNA synthesis [111,112] (Figure 3).
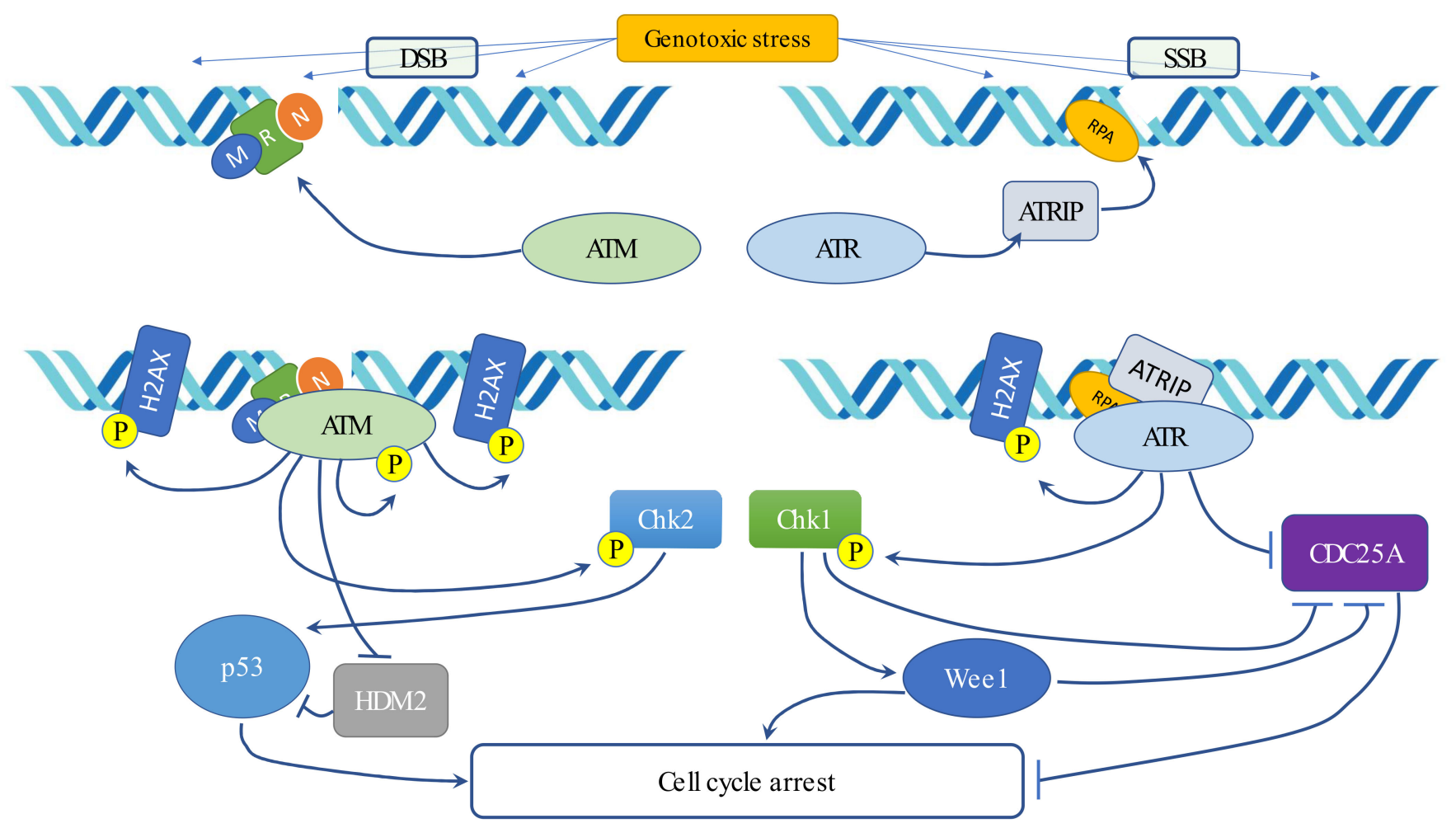

Figure 3. Schematic representation of the components involved in the DNA damage response.

Furthermore, Chk1 is required for homologous recombination repair (HRR), which is a mechanism that is essential in mammals for restoring DNA integrity after DSBs, as well as other lesions; in fact, it promotes the association of chromatin and phosphorylation of RAD51, which is a key protein in HRR [113].

Moreover, Chk1 is required for mitotic spindle checkpoint functioning. During the metaphase, chromosomes are hooked in both their sides by microtubules, forming a 
mitotic spindle coming from opposite poles of the cell; then, they are aligned in the central portion of the mitotic spindle and equally divided to the daughter cells, which receive a chromosomal copy each. If something at the level of alignment does not occur regularly and defects emerge, Chk1 is phosphorylated and, in turn, phosphorylates Aurora B protein kinase. This regulates BubR1 protein, which, together with Mad1 and Mad2, forms an inhibitory ternary complex with the E3 ligase APC and its activator Cdc20 in the mitotic spindle checkpoint. Thus, BubR1 is recruited at the kinetochore level and delays the passage from the metaphase to the anaphase, protecting against chromosomal segregation defects [114-116]. Following the DSB, DNA-PK-mediated DNA repair occurs via the non-homologous end joining (NHEJ) process. In such a process, each broken DNA end is first bound by one $\mathrm{Ku} 70 / 80$ heterodimer and two heterodimers interact together to bridge matching ends. Ku plays a crucial role in NHEJ, recruiting multiple downstream proteins, including the DNA-dependent protein kinase catalytic subunit (DNA-PKcs). In turn, DNA-PKcs interacts with Artemis and DNA ligase IV, enabling NHEJ [99,117].

\section{Cancer Stem Cells and WEE1 Involvement in Radiation Oncology}

Cancer cells are heterogeneous regarding their tumor-initiating properties. In particular, cancer stem cells (CSCs) are a small subset of a tumor population, normally representing $0.1-10 \%$ of all tumor cells, which were identified as tumor-initiating cells. CSCs possess self-renewal potential and persistent tumorigenic capacity that make them different from other tumor cells.

Experimental evidence on tumor cell transplantation, as well as in both isogenic murine models and human xenograft tumor models, demonstrated that the number of CSCs in these experimental tumors defines the therapeutic potential of radiotherapy, thus a higher proportion of CSCs correlates with a higher radio-resistance in the same histopathological tumor type [93,94,118-120]. Additionally, the intrinsic radiosensitivity of CSCs varies between tumors, thereby affecting their radio-curability [121,122]. A recent CSC model, which was developed by our research group, allowed for predicting the radiotherapy treatment efficacy based on the evident concordance between in vitro and in vivo CSC sensitivity to radiotherapy [121]. Notably, the specific CSC in vitro and in vivo sensitivity values correspond to patients' responses to radiotherapy. This approach may be useful for driving clinical decisions for correct therapeutic option management [121].

As a key source of resistance to DNA-damaging treatment in oncology, CSCs were reported to improve DNA repair capacity by enhancing the activation of the DNA damage response compared with differentiated cells $[123,124]$. CSCs contribute to radio- and chemoresistance through a circular mechanism: repeated cycles of DNA-damaging treatments progressively kill the non-stem cells, causing an increase in the CSC fraction within the tumor cell population. The tumor microenvironment can also influence the tumor cell sensitivity or resistance to IR. In particular, it was demonstrated that CSCs are protected from the effects of IR by hypoxia that is mediated by specific hypoxic niches $[93,125]$. Hypoxia might affect CSC proliferation and viability via hypoxia-inducible factors (HIFs) that can induce the expression of OCT4, MYC and NOTCH1, which are crucial for stem cell maintenance in different tissues [126-128]. In addition, the cell-stroma interactions, by means of the integrin-mediated adhesion of cells to the extracellular matrix, increase the tumor cell resistance to IR [129]. As a result, classical therapies become progressively ineffective toward these CSC-enriched tumors [130].

Few studies reported Wee1 inhibition in the particular case of CSCs inducing radiosensitization in glioblastoma $[67,131]$. However, these findings support the concept that the overexpression of checkpoint inhibitors, such as Wee1, could be an adopted protection mechanism in CSCs with sublethal damage induced by conventional radio- and chemotherapy. Therefore, targeting the DNA damage checkpoint response in CSC may sensitize these cells to DNA-damaging techniques and overcome tumor resistances [132]. 


\section{Wee1 Inhibitors}

Wee1 represents an optimal target for the inhibition of the G2-M checkpoint in order to potentiate both radio- and chemotherapy.

In fact, although the purpose of the majority of anti-cancer therapeutic strategies involves cell cycle arrest, Wee1 kinase inhibition triggers mitosis and induces genomic instability, driving cells to follow a replication cycle, with consequential apoptosis for mitotic catastrophe.

This strategy may allow for the dose reduction of conventional therapies, leading to a reduction in toxic side effects while maintaining clinical efficacy; moreover, it may sensitize tumors with poor prognosis to conventional therapies.

Recent studies demonstrated that Wee1 inhibition can be reached with low cytotoxicity through rational drug design $[133,134]$. The only Wee1 inhibitor that is currently used in clinical trials (query on ClinicalTrials.gov, July 2021) (Accessed on 22 September 2021) is AZD1775, combined with DNA damage agents or radiotherapy, which is tolerable and demonstrates promising anticancer activity.

In addition to AZD1775, hundreds of compounds were reported to have inhibitory activity against Wee1 kinase. A recent study classified the Wee1 inhibitors that are reported in scientific literature into five groups on the basis of their chemical core structure (pyridopyrimidine derivatives, pyrazolopyrimidinone derivatives, pyrrolocarbazole derivatives, pyrimidine-based tricyclic molecules and vanillates) [135].

The first small molecule to be reported bearing the pyridopyrimidine core was PD0166285 [87] Although it showed a potent Wee1 inhibition activity (IC50 $=24 \mathrm{nM}$ ) in various cancer cell lines and xenografts $[67,87,136-138]$, its clinical application is limited because of its non-selective Wee1 inhibition. In fact, PD0166285 presents a broad spectrum of inhibitory activity on several tyrosine kinases, including CHK1, MYT1, c-Src, EGFR, FGFR1 and PDGFR $[87,135]$. Due to its poor selectivity, PD0166285's clinical application is limited. Furthermore, starting from the PD0166285 structure, several pyridopyrimidine derivates were synthesized while trying to increase the selectivity for Wee1, but most of them were found to preserve a potent inhibitory activity against c-Src [87,139-141].

Among the Wee1 inhibitors that have the pyrazolopyrimidinone scaffold, there is the known AZD1775. A series of pyrazolopyrimidinone analogs were synthetized [142] and, in 2016, Matheson and collaborators reported a compound (CJM-061) that showed the same Wee1 inhibitory efficacy of AZD1775, but had reduced single-agent cytotoxicity in medulloblastoma cells [133]. On this basis, Matheson et al. developed a series of potent pyrazolopyrimidinone-based Wee1 inhibitors; in particular, they found a compound that showed a stronger inhibition activity and reduced cytotoxicity compared to AZD1775 [134]. However, AZD1775 is the only Wee1 inhibitor that is currently used in clinical trials (query on ClinicalTrials.gov, July 2021).

The third class of Wee1 inhibitors is composed of the pyrrolocarbazole derivatives, all of which are analogs of the lead compound 4-phenylpyrrolecarbazole PD0407824, which is a powerful Wee1/Chk1 inhibitor. PD0407824 was a less potent Wee1 inhibitor compared to PD0166285 but was more selective for Wee1 and CHK1 than for c-Src [143]. Furthermore, it has only been tested on ovarian cancer, where it was shown to positively modulate the cis-platinum response [144]. On the basis of several structure-activity relationship studies $[143,145,146]$, the analogs were designed in order to be more selective for Wee1 than for CHK1 [143]. Furthermore, the study of this class of Wee1 inhibitors has not been advanced into in vivo study, probably because of the broad spectrum of kinase inhibitor activity.

In 2014, Tong et al., aided by molecular modeling and structure-activity relationship studies, designed pyrimidine-based tricyclic molecules that showed potent Wee1 kinase inhibitor activity in both functional and mechanism-based cellular studies. The lead molecule, namely, 31, showed oral efficacy in the NCI-H1299 mouse xenograft model, potentiating the antiproliferative activity of irinotecan [147]. 
It is known that natural polyphenols, including polyphenols present in green tea (epigallocatechin gallate (EGCG)) [148], genistein [149] and curcumin [150], possess potential anticancer activity through inhibiting the proliferation, invasion and metastasis of tumoral cells and the induction of apoptosis, acting on different signaling pathways [148-155].

Starting from the core structure of polyphenols, Lamoral-Theys' group designed and synthesized several di- and trivanillate compounds, with some of them presenting WEE1 inhibitory and anti-tumor activities, probably due to their inhibitory activity against the Aurora A/B/C responsible [156].

Table 2 summerizes the above reported evidence.

Table 2. Wee1 inhibitors. Standard color coding for atoms is used (black—carbon, red—oxygen, blue-nitrogen, green— chlorine, brown-fluorine).

\begin{tabular}{|c|c|c|c|c|c|}
\hline & $\begin{array}{l}\text { Core Chemical } \\
\text { Structure }\end{array}$ & Lead Compounds & $\begin{array}{l}\text { CHK1 } \\
\mathrm{IC}_{50}(\mathrm{nM})\end{array}$ & $\begin{array}{l}\text { WEE1 } \\
\mathrm{IC}_{50}(\mathrm{nM})\end{array}$ & References \\
\hline $\begin{array}{l}\text { Pyridopyrimidine } \\
\text { derivatives }\end{array}$ & & $\begin{array}{r}\mathrm{PD} 0166285 \\
l_{1,3}\end{array}$ & 72 & 24 & [86] \\
\hline
\end{tabular}

Pyrazolopyrimidinone derivatives<smiles>O=C1N=Nc2cncnc21</smiles>

CJM-061<smiles>C=CCC1C(C)c2cnc(Nc3ccc(C4CCC(C(=O)ON)CC4)cc3)cc2C1c1cccc(C(C)(C)C)c1</smiles>

AZD1775

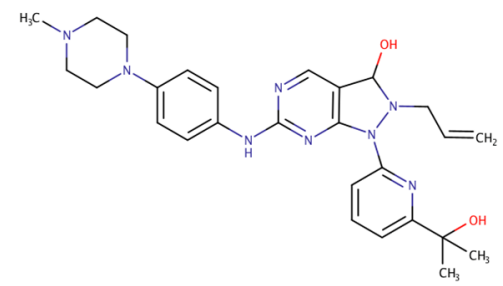

Pyrrolocarbazole derivatives<smiles>C1=Nc2ccc3c(c2=C1)=Nc1ccccc1-3</smiles><smiles>O=c1[nH]c(=O)c2c1c(-c1ccccc1)cc1c3[nH]c4ccc(O)cc4c3c12</smiles>

31

Pyrimidine-based tricyclic molecules<smiles>[R]Nc1ncc2c(=O)n([AlH2])c3nccn3c2n1</smiles><smiles>CN1Cc2cc(Nc3ncc4c(=O)n(-c5c(F)cccc5Cl)c5nccn5c4n3)ccc2C(C)(C)C1</smiles> 
Table 2. Cont.

$\begin{array}{llll}\begin{array}{l}\text { Core Chemical } \\ \text { Structure }\end{array} & \text { Lead Compounds } & \begin{array}{l}\text { CHKE1 } \\ \mathrm{IC}_{50} \text { (nM) }\end{array} \\ \mathrm{IC}_{50} \text { (nM) }\end{array}$

\section{Wee1 Inhibition Sensitizes Response to Chemo/Radiotherapy}

Among the Wee1 inhibitors, only AZD1775 is currently used in clinical trials. Several studies show its ability to potentiate the activity of chemotherapeutic drugs and radiotherapy. Several studies indicate that AZD1775's sensitizing effect is selective only in p53-deficient tumors $[142,157,158]$, although other evidence demonstrates that Wee1 inhibition can independently sensitize cancer cells to chemotherapeutics via p53 functionality [91].

In particular, in advanced squamous cell carcinoma of the head and neck (HNSCC), it was shown that a combination of AZD1775 and cisplatin can overcome cisplatin resistance, which is particularly high for patients whose tumor presents a mutation in the TP53 gene [159]. Other studies suggest a similar sensitizing effect in the radiation response in pontine gliomas [160], glioblastoma [131] and pancreatic cancer [161]. So far, there are 11 clinical trials testing AZD1775 in combination with various chemotherapeutic agents, 5 in combination with both chemo and radiotherapy and 2 in combination with only radiotherapy. Table 3 lists only the completed clinical trials with reported results.

Table 3. Registered clinical trial on Wee1 inhibitors.

\begin{tabular}{|c|c|c|c|c|}
\hline & Title & Conditions & Interventions & $\begin{array}{l}\text { ClinicalTrial.gov } \\
\text { Identifier } \\
\text { Number }\end{array}$ \\
\hline 1 & $\begin{array}{l}\text { WEE1 Inhibitor with Cisplatin and } \\
\text { Radiotherapy: ATrial in Head and } \\
\text { Neck Cancer }\end{array}$ & $\begin{array}{l}\text {-Hypopharynx squamous cell carcinoma } \\
\text {-Oral cavity squamous cell carcinoma } \\
\text {-Larynx cancer }\end{array}$ & $\begin{array}{l}\text {-AZD1775 } \\
\text {-Cisplatin } \\
\text {-Radiotherapy }\end{array}$ & NCT03028766 \\
\hline 2 & $\begin{array}{l}\text { WEE1 Inhibitor AZD1775 with or } \\
\text { without } \\
\text { Cytarabine in Treating Patients } \\
\text { with Advanced Acute Myeloid } \\
\text { Leukemia or Myelodysplastic } \\
\text { Syndrome }\end{array}$ & $\begin{array}{l}\text {-Chronic myelomonocytic leukemia } \\
\text {-Myelodysplastic syndrome with } \\
\text { isolated del(5q) } \\
\text {-Myelodysplastic/myeloproliferative } \\
\text { neoplasm } \\
\text {-Previously treated myelodysplastic } \\
\text { syndrome } \\
\text {-Recurrent adult acute myeloid leukemia } \\
\text {-Untreated adult acute myeloid leukemia }\end{array}$ & $\begin{array}{l}\text {-AZD1775 } \\
\text {-Cytarabine }\end{array}$ & NCT02666950 \\
\hline
\end{tabular}


Table 3. Cont.

\begin{tabular}{|c|c|c|c|c|}
\hline & Title & Conditions & Interventions & $\begin{array}{l}\text { ClinicalTrial.gov } \\
\text { Identifier } \\
\text { Number }\end{array}$ \\
\hline 3 & $\begin{array}{l}\text { Phase Ib Study AZD1775 in } \\
\text { Combination with } \\
\text { Carboplatin and Paclitaxel in } \\
\text { Adult Asian Patients with Solid } \\
\text { Tumours }\end{array}$ & Advanced solid tumors & $\begin{array}{l}\text {-AZD1775 } \\
\text {-Paclitaxel } \\
\text {-Carboplatin }\end{array}$ & NCT02341456 \\
\hline 4 & $\begin{array}{l}\text { Cisplatin with or without WEE1 } \\
\text { Inhibitor MK-1775 in Treating } \\
\text { Patients with Recurrent or } \\
\text { Metastatic Head and Neck Cancer }\end{array}$ & $\begin{array}{l}\text {-Recurrent hypopharyngeal squamous } \\
\text { cell carcinoma } \\
\text {-Recurrent laryngeal squamous cell } \\
\text { carcinoma } \\
\text {-Recurrent laryngeal verrucous } \\
\text { carcinoma } \\
\text {-Recurrent lip and oral cavity squamous } \\
\text { cell carcinoma } \\
\text {-Recurrent metastatic squamous cell } \\
\text { carcinoma in the neck with an occult } \\
\text { primary } \\
\text {-another } 24 \text { tumors }\end{array}$ & $\begin{array}{l}\text {-MK-1775 } \\
\text {-Cisplatin }\end{array}$ & NCT02196168 \\
\hline 5 & $\begin{array}{l}\text { Ph II Trial of Carboplatin and } \\
\text { Pemetrexed with or without } \\
\text { AZD1775 for Untreated Lung } \\
\text { Cancer }\end{array}$ & $\begin{array}{l}\text { Previously untreated stage IV } \\
\text { non-squamous non-small cell lung } \\
\text { cancer }\end{array}$ & $\begin{array}{l}\text {-AZD1775 } \\
\text {-Pemetrexed } \\
\text {-Carboplatin }\end{array}$ & NCT02087241 \\
\hline 6 & $\begin{array}{l}\text { Dose Escalation Trial of AZD1775 } \\
\text { and Gemcitabine (+Radiation) for } \\
\text { Unresectable Adenocarcinoma of } \\
\text { the Pancreas }\end{array}$ & Adenocarcinoma of the pancreas & $\begin{array}{l}\text {-AZD-1775 } \\
\text {-Gemcitabine } \\
\text {-Radiotherapy }\end{array}$ & NCT02037230 \\
\hline 7 & $\begin{array}{l}\text { A Study of MK-1775 in } \\
\text { Combination with } \\
\text { Topotecan/Cisplatin in } \\
\text { Participants with Cervical Cancer } \\
\text { (MK-1775-008) }\end{array}$ & Cervical cancer & $\begin{array}{l}\text {-MK-1775 } \\
\text {-Topotecan } \\
\text {-Cisplatin }\end{array}$ & NCT01076400 \\
\hline 8 & $\begin{array}{l}\text { A Dose Escalation Study of } \\
\text { MK-1775 in } \\
\text { Combination with Either } \\
\text { Gemcitabine, Cisplatin, or } \\
\text { Carboplatin in Adults with } \\
\text { Advanced Solid Tumors } \\
\text { (MK-1775-001) }\end{array}$ & Solid tumors & $\begin{array}{l}\text {-MK-1775 } \\
\text {-Gemcitabine } \\
\text {-Cisplatin } \\
\text {-Carboplatin }\end{array}$ & NCT00648648 \\
\hline
\end{tabular}

\section{Conclusions}

Developing novel strategies to contrast local tumor cell survival and to, consequently, avoid the insurgence of metastasis is the principal aim of the researchers operating in the oncology field. As functionally impaired p53 is one of the principal hallmarks of tumor cells, they rely on remaining checkpoints to survive and proliferate. From this perspective, Wee1 is surely a prominent target to use in clinical practice for its dual role as gatekeeper in both the S-phase and G2/M transition. While most kinase inhibition strategies aim to arrest the cell cycle to block proliferation, WEE1 inhibition allows for mitosis to occur in cells with heavy DNA damage. This phenomenon increases the amplification of genomic instability through cellular replication cycles, which makes replication errors permanent. Cell cycle progression, when DNA damage occurs, leads to cells quickly accumulating a 
great number of mutations that make them unable to survive. Thus, through its inhibition, it might be possible to increase the effectiveness of DNA-damaging treatments, such as radiotherapy, forcing tumor cells to enter into mitosis, even with damaged DNA. This, finally, leads them to mitotic catastrophe and subsequent cell death.

Wee1 inhibition may allow for the reduction of the dose of cytotoxic chemotherapy, thus improving the safety profiles. It may also be employed to sensitize resistant tumors to conventional therapies when they are not effective as monotherapy.

Author Contributions: F.E., R.G. wrote the manuscript and designed the tables, G.R. and C.P. contributed to the writing of the manuscript, S.F. designed the figures and made the critical revision of the manuscript. All authors have read and agreed to the published version of the manuscript.

Funding: This research received no external funding.

Data Availability Statement: Data supporting reported evidences can be obtained from the original sources (please see reference), data from clinical trials can be retrieved from www.ClinicalTrial.gov.

Acknowledgments: The authors thank Aurelio Lorico for help with English language editing.

Conflicts of Interest: The authors declare no conflict of interest.

\section{References}

1. Lim, S.; Kaldis, P. Cdks, cyclins and CKIs: Roles beyond cell cycle regulation. Development 2013, 140, 3079-3093. [CrossRef]

2. Poon, R.Y.C. Cell Cycle Control: A System of Interlinking Oscillators. Methods Mol. Biol. 2016, 1342, 3-19. [CrossRef]

3. Beetham, K.L.; Tolmach, L.J. The Action of Caffeine on X-Irradiated HeLa Cells. V. Identity of the Sector of Cells That Expresses Potentially Lethal Damage in G1 and G2. Radiat. Res. 1982, 91, 199-211. [CrossRef]

4. Dixon, H.; Norbury, C.J. Therapeutic Exploitation of Checkpoint Defects in Cancer Cells Lacking p53 Function. Cell Cycle 2002, 1, 362-368. [CrossRef] [PubMed]

5. Benada, J.; Macurek, L. Targeting the Checkpoint to Kill Cancer Cells. Biomolecules 2015, 5, 1912-1937. [CrossRef] [PubMed]

6. Santo, L.; Siu, K.T.; Raje, N. Targeting Cyclin-Dependent Kinases and Cell Cycle Progression in Human Cancers. Semin. Oncol. 2015, 42, 788-800. [CrossRef] [PubMed]

7. Schmidt, M.; Rohe, A.; Platzer, C.; Najjar, A.; Erdmann, F.; Sippl, W. Regulation of G2/M Transition by Inhibition of WEE1 and PKMYT1 Kinases. Molecules 2017, 22, 2045. [CrossRef]

8. Nakanishi, M.; Ando, H.; Watanabe, N.; Kitamura, K.; Ito, K.; Okayama, H.; Miyamoto, T.; Agui, T.; Sasaki, M. Identification and characterization of human Wee1B, a new member of the Wee1 family of Cdk-inhibitory kinases. Genes Cells 2000, 5, 839-847. [CrossRef]

9. Russell, P.; Nurse, P. Negative regulation of mitosis by wee ${ }^{+}$, a gene encoding a protein kinase homolog. Cell 1987, 49, 559-567. [CrossRef]

10. Gould, K.; Nurse, P. Tyrosine phosphorylation of the fission yeast $\mathrm{cdc}^{+}$protein kinase regulates entry into mitosis. Nature 1989, 342, 39-45. [CrossRef]

11. McGowan, C.; Russell, P. Cell cycle regulation of human WEE1. EMBO J. 1995, 14, 2166-2175. [CrossRef]

12. Squire, C.; Dickson, J.M.; Ivanovic, I.; Baker, E. Structure and Inhibition of the Human Cell Cycle Checkpoint Kinase, Wee1A Kinase: An Atypical Tyrosine Kinase with a Key Role in CDK1 Regulation. Structure 2005, 13, 541-550. [CrossRef] [PubMed]

13. Mueller, P.R.; Coleman, T.R.; Kumagai, A.; Dunphy, W.G. Myt1: A Membrane-Associated Inhibitory Kinase That Phosphorylates Cdc2 on Both Threonine-14 and Tyrosine-15. Science 1995, 270, 86-90. [CrossRef] [PubMed]

14. Liu, F.; Stanton, J.J; Wu, Z.; Piwnica-Worms, H. The human Myt1 kinase preferentially phosphorylates Cdc2 on threonine 14 and localizes to the endoplasmic reticulum and Golgi complex. Mol. Cell. Biol. 1997, 17, 571-583. [CrossRef] [PubMed]

15. Wells, N.; Watanabe, N.; Tokusumi, T.; Jiang, W.; Verdecia, M.; Hunter, T. The C-terminal domain of the Cdc2 inhibitory kinase Myt1 interacts with Cdc2 complexes and is required for inhibition of G(2)/M progression. J. Cell Sci. 1999, 112, 3361-3371. [CrossRef]

16. Booher, R.N.; Holman, P.S.; Fattaey, A. Human Myt1 Is a Cell Cycle-regulated Kinase That Inhibits Cdc2 but Not Cdk2 Activity. J. Biol. Chem. 1997, 272, 22300-22306. [CrossRef]

17. Richard, C.W.; Boehnke, M.; Berg, D.J.; Lichy, J.H.; Meeker, T.C.; Hauser, E.; Myers, R.M.; Cox, D.R. A radiation hybrid map of the distal short arm of human chromosome 11, containing the Beckwith-Weidemann and associated embryonal tumor disease loci. Am. J. Hum. Genet. 1993, 52, 915-921.

18. Thuriaux, P.; Nurse, P.; Carter, B. Mutants altered in the control co-ordinating cell division with cell growth in the fission yeast Schizosaccharomyces pombe. MGG Mol. Gen. Genet. 1978, 161, 215-220. [CrossRef] [PubMed]

19. Nurse, P.; Thuriaux, P. Regulatory genes controlling mitosis in the fission yeast Schizosaccharomyces pombe. Genetics 1980, 96, 627-637. [CrossRef]

20. Igarashi, M.; Nagata, A.; Jinno, S.; Suto, K.; Okayama, H. Wee1+-like gene in human cells. Nature 1991, 353, 80-83. [CrossRef] 
21. McGowan, C.; Russell, P. Human Wee1 kinase inhibits cell division by phosphorylating p34cdc2 exclusively on Tyr15. EMBO J. 1993, 12, 75-85. [CrossRef]

22. Nurse, P. Universal control mechanism regulating onset of M-phase. Nature 1990, 344, 503-508. [CrossRef]

23. Mueller, P.R.; Coleman, T.R.; Dunphy, W.G. Cell cycle regulation of a Xenopus Wee1-like kinase. Mol. Biol. Cell 1995, 6, 119-134. [CrossRef]

24. Booher, R.; Deshaies, R.; Kirschner, M. Properties of Saccharomyces cerevisiae wee1 and its differential regulation of p34CDC28 in response to $\mathrm{G} 1$ and $\mathrm{G} 2$ cyclins. EMBO J. 1993, 12, 3417-3426. [CrossRef]

25. Campbell, S.D.; Sprenger, F.; Edgar, B.A.; O'Farrell, P.H. Drosophila Wee1 kinase rescues fission yeast from mitotic catastrophe and phosphorylates Drosophila Cdc2 in vitro. Mol. Biol. Cell 1995, 6, 1333-1347. [CrossRef] [PubMed]

26. Honda, R.; Tanaka, H.; Ohba, Y.; Yasuda, H. Mouse p87wee1 kinase is regulated by M-phase specific phosphorylation. Chromosome Res. 1995, 3, 300-308. [CrossRef] [PubMed]

27. Boardman, P.E.; Sanz-Ezquerro, J.; Overton, I.M.; Burt, D.W.; Bosch, E.; Fong, W.T.; Tickle, C.; Brown, W.R.; Wilson, S.A.; Hubbard, S.J. A comprehensive collection of chicken cDNAs. Curr. Biol. 2002, 12, 1965-1969. [CrossRef]

28. Hirayama, J.; Cardone, L.; Doi, M.; Sassone-Corsi, P. Common pathways in circadian and cell cycle clocks: Light-dependent activation of Fos/AP-1 in zebrafish controls CRY-1a and WEE-1. Proc. Natl. Acad. Sci. USA 2005, 102, 10194-10199. [CrossRef] [PubMed]

29. Obsilova, V.; Obsil, T. The 14-3-3 Proteins as Important Allosteric Regulators of Protein Kinases. Int. J. Mol. Sci. 2020, 21, 8824. [CrossRef]

30. Wang, Y.; Jacobs, C.; Hook, K.E.; Duan, H.; Booher, R.N.; Sun, Y. Binding of 14-3-3 $\beta$ to the carboxyl terminus of Wee1 increases Wee1 stability, kinase activity, and G2-M cell population. Cell Growth Differ. 2000, 11, 211-219. [PubMed]

31. Rothblum-Oviatt, C.J.; E Ryan, C.; Piwnica-Worms, H. 14-3-3 binding regulates catalytic activity of human Wee1 kinase. Cell Growth Differ. 2001, 12, 581-589.

32. Aligue, R.; Akhavan-Niak, H.; Russell, P. A role for Hsp90 in cell cycle control: Wee1 tyrosine kinase activity requires interaction with Hsp90. EMBO J. 1994, 13, 6099-6106. [CrossRef] [PubMed]

33. Goes, F.S.; Martin, J. Hsp90 chaperone complexes are required for the activity and stability of yeast protein kinases Mik1, Wee1 and Swe1. Eur. J. Biochem. 2001, 268, 2281-2289. [CrossRef] [PubMed]

34. Mollapour, M.; Tsutsumi, S.; Donnelly, A.C.; Beebe, K.; Tokita, M.J.; Lee, M.-J.; Lee, S.; Morra, G.; Bourboulia, D.; Scroggins, B.T.; et al. Swe1Wee1-Dependent Tyrosine Phosphorylation of Hsp90 Regulates Distinct Facets of Chaperone Function. Mol. Cell 2010, 37, 333-343. [CrossRef]

35. Iwai, A.; Bourboulia, D.; Mollapour, M.; Jensen-Taubman, S.; Lee, S.; Donnelly, A.C.; Yoshida, S.; Miyajima, N.; Tsutsumi, S.; Smith, A.K.; et al. Combined inhibition of Wee1 and Hsp90 activates intrinsic apoptosis in cancer cells. Cell Cycle 2012, 11, 3649-3655. [CrossRef]

36. Sasaki, M.; Terabayashi, T.; Weiss, S.M.; Ferby, I. The Tumor Suppressor MIG6 Controls Mitotic Progression and the G2/M DNA Damage Checkpoint by Stabilizing the WEE1 Kinase. Cell Rep. 2018, 24, 1278-1289. [CrossRef]

37. Heald, R.; McLoughlin, M.; McKeon, F. Human wee1 maintains mitotic timing by protecting the nucleus from cytoplasmically activated cdc2 kinase. Cell 1993, 74, 463-474. [CrossRef]

38. Watanabe, N.; Broome, M.; Hunter, T. Regulation of the human WEE1Hu CDK tyrosine 15-kinase during the cell cycle. EMBO J. 1995, 14, 1878-1891. [CrossRef]

39. Dunphy, W.G.; Brizuela, L.; Beach, D.; Newport, J. The Xenopus cdc2 protein is a component of MPF, a cytoplasmic regulator of mitosis. Cell 1988, 54, 423-431. [CrossRef]

40. Gautier, J.; Norbury, C.; Lohka, M.; Nurse, P.; Maller, J. Purified maturation-promoting factor contains the product of a Xenopus homolog of the fission yeast cell cycle control gene cdc2 ${ }^{+}$. Cell 1988, 54, 433-439. [CrossRef]

41. Murray, A.W. Turning on mitosis. Curr. Biol. 1993, 3, 291-293. [CrossRef]

42. Parker, L.L.; Piwnica-Worms, H. Inactivation of the p34cdc2-cyclin B complex by the human WEE1 tyrosine kinase. Science 1992, 257, 1955-1957. [CrossRef] [PubMed]

43. Solomon, M.J.; Lee, T.; Kirschner, M.W. Role of phosphorylation in p34cdc2 activation: Identification of an activating kinase. Mol. Biol. Cell 1992, 3, 13-27. [CrossRef]

44. Larochelle, S.; Merrick, K.A.; Terret, M.-E.; Wohlbold, L.; Barboza, N.M.; Zhang, C.; Shokat, K.M.; Jallepalli, P.V.; Fisher, R.P. Requirements for Cdk7 in the Assembly of Cdk1/Cyclin B and Activation of Cdk2 Revealed by Chemical Genetics in Human Cells. Mol. Cell 2007, 25, 839-850. [CrossRef] [PubMed]

45. Ayad, N.G.; Rankin, S.; Murakami, M.; Jebanathirajah, J.; Gygi, S.; Kirschner, M.W. Tome-1, a Trigger of Mitotic Entry, Is Degraded during G1 via the APC. Cell 2003, 113, 101-113. [CrossRef]

46. Watanabe, N.; Arai, H.; Nishihara, Y.; Taniguchi, M.; Watanabe, N.; Hunter, T.; Osada, H. M-phase kinases induce phosphodependent ubiquitination of somatic Wee1 by SCF ${ }^{\beta-T r C P}$. Proc. Natl. Acad. Sci. USA 2004, 101, 4419-4424. [CrossRef]

47. Smith, A.; Simanski, S.; Fallahi, M.; Ayad, N.G. Redundant Ubiquitin Ligase Activities Regulate Wee1 Degradation and Mitotic Entry. Cell Cycle 2007, 6, 2795-2799. [CrossRef]

48. Beck, H.; Nähse, V.; Larsen, M.S.Y.; Groth, P.; Clancy, T.; Lees, M.; Jørgensen, M.; Helleday, T.; Syljuåsen, R.G.; Sorensen, C. Regulators of cyclin-dependent kinases are crucial for maintaining genome integrity in S phase. J. Cell Biol. 2010, 188, 629-638. [CrossRef] 
49. Martín, Y.; Domínguez-Kelly, R.; Freire, R. Novel insights into maintaining genomic integrity: Wee1 regulating Mus81/Eme1. Cell Div. 2011, 6, 21. [CrossRef]

50. Duda, H.; Arter, M.; Gloggnitzer, J.; Teloni, F.; Wild, P.; Blanco, M.G.; Altmeyer, M.; Matos, J. A Mechanism for Controlled Breakage of Under-replicated Chromosomes during Mitosis. Dev. Cell 2016, 39, 740-755. [CrossRef]

51. Domínguez-Kelly, R.; Martín, Y.; Koundrioukoff, S.; Tanenbaum, M.E.; Smits, V.A.; Medema, R.; Debatisse, M.; Freire, R. Wee1 controls genomic stability during replication by regulating the Mus81-Eme1 endonuclease. J. Cell Biol. 2011, 194, 567-579. [CrossRef]

52. Beck, H.; Nähse-Kumpf, V.; Larsen, M.S.Y.; O’Hanlon, K.A.; Patzke, S.; Holmberg, C.; Mejlvang, J.; Groth, A.; Nielsen, O.; Syljuåsen, R.G.; et al. Cyclin-Dependent Kinase Suppression by WEE1 Kinase Protects the Genome through Control of Replication Initiation and Nucleotide Consumption. Mol. Cell. Biol. 2012, 32, 4226-4236. [CrossRef]

53. Técher, H.; Koundrioukoff, S.; Carignon, S.; Wilhelm, T.; Millot, G.A.; Lopez, B.; Brison, O.; Debatisse, M. Signaling from Mus81-Eme2-Dependent DNA Damage Elicited by Chk1 Deficiency Modulates Replication Fork Speed and Origin Usage. Cell Rep. 2016, 14, 1114-1127. [CrossRef] [PubMed]

54. Vassilopoulos, A.; Tominaga, Y.; Kim, H.-S.; Lahusen, T.; Li, B.; Yu, H.; Gius, D.; Deng, C.-X. WEE1 murine deficiency induces hyper-activation of APC/C and results in genomic instability and carcinogenesis. Oncogene 2015, 34, 3023-3035. [CrossRef] [PubMed]

55. Mahajan, K.; Fang, B.; Koomen, J.M.; Mahajan, N.P. H2B Tyr37 phosphorylation suppresses expression of replication-dependent core histone genes. Nat. Struct. Mol. Biol. 2012, 19, 930-937. [CrossRef]

56. Tominaga, Y.; Li, C.; Wang, R.-H.; Deng, C.-X. Murine Wee1 Plays a Critical Role in Cell Cycle Regulation and Pre-Implantation Stages of Embryonic Development. Int. J. Biol. Sci. 2006, 2, 161-170. [CrossRef] [PubMed]

57. Eom, M.; Han, A.; Lee, M.J.; Park, K.H. Expressional Difference of RHEB, HDAC1, and WEE1 Proteins in the Stromal Tumors of the Breast and Their Significance in Tumorigenesis. Korean J. Pathol. 2012, 46, 324-330. [CrossRef]

58. Backert, S.; Gelos, M.; Kobalz, U.; Hanski, M.-L.; Mann, B.; Gratchev, A.; Mansmann, U.; Moyer, M.P.; Riecken, E.-O.; Hanski, C. Differential gene expression in colon carcinoma cells and tissues detected with a cDNA array. Int. J. Cancer 1999, 82, 868-874. [CrossRef]

59. Yoshida, T.; Tanaka, S.; Mogi, A.; Shitara, Y.; Kuwano, H. The clinical significance of Cyclin B1 and Wee1 expression innon-smallcell lung cancer. Ann. Oncol. 2004, 15, 252-256. [CrossRef]

60. Chen, X.; Zhang, N. Downregulation of lncRNA NEAT1_2 radiosensitizes hepatocellular carcinoma cells through regulation of miR-101-3p/WEE1 axis. Cell Biol. Int. 2019, 43, 44-55. [CrossRef]

61. Bhattacharya, A.; Schmitz, U.; Wolkenhauer, O.; Schönherr, M.; Raatz, Y.; Kunz, M. Regulation of cell cycle checkpoint kinase WEE1 by miR-195 in malignant melanoma. Oncogene 2013, 32, 3175-3183. [CrossRef] [PubMed]

62. Leary, A.; Auguste, A.; Mesnage, S. DNA damage response as a therapeutic target in gynecological cancers. Curr. Opin. Oncol. 2016, 28, 404-411. [CrossRef] [PubMed]

63. Wu, J.; Li, Y.; Dang, Y.-Z.; Gao, H.-X.; Jiang, J.-L.; Chen, Z.-N. HAb18G/CD147 Promotes Radioresistance in Hepatocellular Carcinoma Cells: A Potential Role for Integrin $\beta 1$ Signaling. Mol. Cancer Ther. 2015, 14, 553-563. [CrossRef]

64. Yu, X.; Li, Z.; Zheng, H.; Chan, M.T.V.; Wu, W.K.K. NEAT1: A novel cancer-related long non-coding RNA. Cell Prolif. 2017, 50, e12329. [CrossRef]

65. Tibes, R.; Bogenberger, J.M.; Chaudhuri, L.; Hagelstrom, R.T.; Chow, D.; Buechel, M.E.; Gonzales, I.M.; Demuth, T.; Slack, J.; Mesa, R.A.; et al. RNAi screening of the kinome with cytarabine in leukemias. Blood 2012, 119, 2863-2872. [CrossRef]

66. Iorns, E.; Lord, C.; Grigoriadis, A.; McDonald, S.; Fenwick, K.; Mackay, A.; Mein, C.; Natrajan, R.; Savage, K.; Tamber, N.; et al. Integrated Functional, Gene Expression and Genomic Analysis for the Identification of Cancer Targets. PLoS ONE 2009, 4, e5120. [CrossRef]

67. Mir, S.E.; Hamer, P.C.D.W.; Krawczyk, P.M.; Balaj, L.; Claes, A.; Niers, J.M.; Van Tilborg, A.A.; Zwinderman, A.H.; Geerts, D.; Kaspers, G.J.; et al. In silico analysis of kinase expression identifies WEE1 as a gatekeeper against mitotic catastrophe in glioblastoma. Cancer Cell 2010, 18, 244-257. [CrossRef] [PubMed]

68. Masaki, T.; Shiratori, Y.; Rengifo, W.; Igarashi, K.; Yamagata, M.; Kurokohchi, K.; Uchida, N.; Miyauchi, Y.; Yoshiji, H.; Watanabe, S.; et al. Cyclins and cyclin-dependent kinases: Comparative study of hepatocellular carcinoma versus cirrhosis. Hepatology 2003, 37, 534-543. [CrossRef]

69. Harris, P.S.; Venkataraman, S.; Alimova, I.; Birks, D.K.; Balakrishnan, I.; Cristiano, B.; Donson, A.M.; Dubuc, A.M.; Taylor, M.D.; Foreman, N.K.; et al. Integrated genomic analysis identifies the mitotic checkpoint kinase WEE1 as a novel therapeutic target in medulloblastoma. Mol. Cancer 2014, 13, 72. [CrossRef] [PubMed]

70. Mueller, S.; Hashizume, R.; Yang, X.; Kolkowitz, I.; Olow, A.K.; Phillips, J.; Smirnov, I.; Tom, M.W.; Prados, M.D.; James, C.D.; et al. Targeting Wee1 for the treatment of pediatric high-grade gliomas. Neuro Oncol. 2014, 16, 352-360. [CrossRef]

71. Music, D.; Dahlrot, R.; Hermansen, S.K.; Hjelmborg, J.; De Stricker, K.; Hansen, S.; Kristensen, B.W. Expression and prognostic value of the WEE1 kinase in gliomas. J. Neuro Oncol. 2016, 127, 381-389. [CrossRef]

72. Slipicevic, A.; Holth, A.; Hellesylt, E.; Tropé, C.G.; Davidson, B.; Flørenes, V.A. Wee1 is a novel independent prognostic marker of poor survival in post-chemotherapy ovarian carcinoma effusions. Gynecol. Oncol. 2014, 135, 118-124. [CrossRef]

73. Magnussen, G.I.; Hellesylt, E.; Nesland, J.M.; Tropé, C.G.; Flørenes, V.A.; Holm, R. High expression of wee1 is associated with malignancy in vulvar squamous cell carcinoma patients. BMC Cancer 2013, 13, 288. [CrossRef] 
74. Magnussen, G.I.; Holm, R.; Emilsen, E.; Rosnes, A.K.; Slipicevic, A.; Flørenes, V.A. High expression of Wee1 is associated with poor disease-free survival in malignant melanoma: Potential for targeted therapy. PLoS ONE 2012, 7, e38254. [CrossRef] [PubMed]

75. Mak, J.P.Y.; Man, W.Y.; Chow, J.P.; Ma, H.T.; Poon, R.Y. Pharmacological inactivation of CHK1 and WEE1 induces mitotic catastrophe in nasopharyngeal carcinoma cells. Oncotarget 2015, 6, 21074-21084. [CrossRef] [PubMed]

76. Aarts, M.; Sharpe, R.; Garcia-Murillas, I.; Gevensleben, H.; Hurd, M.S.; Shumway, S.D.; Toniatti, C.; Ashworth, A.; Turner, N.C. Forced Mitotic Entry of S-Phase Cells as a Therapeutic Strategy Induced by Inhibition of WEE1. Cancer Discov. 2012, 2, 524-539. [CrossRef] [PubMed]

77. Kogiso, T.; Nagahara, H.; Hashimoto, E.; Ariizumi, S.; Yamamoto, M.; Shiratori, K. Efficient Induction of Apoptosis by Wee1 Kinase Inhibition in Hepatocellular Carcinoma Cells. PLoS ONE 2014, 9, e100495. [CrossRef] [PubMed]

78. Pappano, W.N.; Zhang, Q.; Tucker, L.A.; Tse, C.; Wang, J. Genetic inhibition of the atypical kinase Wee1 selectively drives apoptosis of p53 inactive tumor cells. BMC Cancer 2014, 14, 430. [CrossRef]

79. Hamer, P.C.D.W.; Mir, S.E.; Noske, D.; Van Noorden, C.J.F.; Würdinger, T. WEE1 Kinase Targeting Combined with DNA-Damaging Cancer Therapy Catalyzes Mitotic Catastrophe. Clin. Cancer Res. 2011, 17, 4200-4207. [CrossRef] [PubMed]

80. Zhang, M.; Dominguez, D.; Chen, S.; Fan, J.; Qin, L.; Long, A.; Li, X.; Zhang, Y.; Shi, H.; Zhang, B. WEE1 inhibition by MK1775 as a single-agent therapy inhibits ovarian cancer viability. Oncol. Lett. 2017, 14, 3580-3586. [CrossRef] [PubMed]

81. Kreahling, J.M.; Gemmer, J.Y.; Reed, D.; Letson, D.; Bui, M.; Altiok, S. MK1775, a Selective Wee1 Inhibitor, Shows Single-Agent Antitumor Activity against Sarcoma Cells. Mol. Cancer Ther. 2012, 11, 174-182. [CrossRef] [PubMed]

82. Zhou, B.-B.S.; Bartek, J. Targeting the checkpoint kinases: Chemosensitization versus chemoprotection. Nat. Rev. Cancer 2004, 4 , 216-225. [CrossRef]

83. Ku, B.M.; Bae, Y.-H.; Koh, J.; Sun, J.-M.; Lee, S.-H.; Ahn, J.S.; Park, K.; Ahn, M.-J. Mutational status of TP53 defines the efficacy of Wee1 inhibitor AZD1775 in KRAS-mutant non-small cell lung cancer. Oncotarget 2017, 8, 67526-67537. [CrossRef]

84. Bauman, J.E.; Chung, C.H. CHK It Out! Blocking WEE Kinase Routs TP53 Mutant Cancer. Clin. Cancer Res. 2014, 20, 4173-4175. [CrossRef]

85. Hirai, H.; Arai, T.; Okada, M.; Nishibata, T.; Kobayashi, M.; Sakai, N.; Imagaki, K.; Ohtani, J.; Sakai, T.; Yoshizumi, T.; et al. MK1775, a small molecule Wee1 inhibitor, enhances anti-tumor efficacy of various DNA-damaging agents, including 5-fluorouracil. Cancer Biol. Ther. 2010, 9, 514-522. [CrossRef]

86. PosthumaDeBoer, J.; Würdinger, T.; Graat, H.C.; van Beusechem, V.W.; Helder, M.N.; van Royen, B.J.; Kaspers, G.J. WEE1 inhibition sensitizes osteosarcoma to radiotherapy. BMC Cancer 2011, 11, 156. [CrossRef] [PubMed]

87. Wang, Y.; Li, J.; Booher, R.N.; Kraker, A.; Lawrence, T.; Leopold, W.R.; Sun, Y. Radiosensitization of p53 mutant cells by PD0166285, a novel G(2) checkpoint abrogator. Cancer Res. 2001, 61, 8211-8217. [PubMed]

88. Li, J.; Wang, Y.; Sun, Y.; Lawrence, T.S. Wild-type TP53 inhibits G(2)-phase checkpoint abrogation and radiosensitization induced by PD0166285, a WEE1 kinase inhibitor. Radiat. Res. 2002, 157, 322-330. [CrossRef]

89. Barbosa, R.S.; Dantonio, P.M.; Guimarães, T.; de Oliveira, M.B.; Alves, V.L.F.; Sandes, A.F.; Fernando, R.C.; Colleoni, G.W. Sequential combination of bortezomib and WEE1 inhibitor, MK-1775, induced apoptosis in multiple myeloma cell lines. Biochem. Biophys. Res. Commun. 2019, 519, 597-604. [CrossRef]

90. Porter, C.C.; Kim, J.; Fosmire, S.; Gearheart, C.M.; Van Linden, A.; Baturin, D.; Zaberezhnyy, V.; Patel, P.R.; Gao, D.; Tan, A.C.; et al. Integrated genomic analyses identify WEE1 as a critical mediator of cell fate and a novel therapeutic target in acute myeloid leukemia. Leukemia 2012, 26, 1266-1276. [CrossRef]

91. Van Linden, A.A.; Baturin, D.; Ford, J.B.; Fosmire, S.P.; Gardner, L.; Korch, C.; Reigan, P.; Porter, C.C. Inhibition of Wee1 Sensitizes Cancer Cells to Antimetabolite Chemotherapeutics In Vitro and In Vivo, Independent of p53 Functionality. Mol. Cancer Ther. 2013, 12, 2675-2684. [CrossRef]

92. Atun, R.; Jaffray, D.; Barton, M.; Bray, F.; Baumann, M.; Vikram, B.; Hanna, T.; Knaul, F.M.; Lievens, Y.; Lui, T.; et al. Expanding global access to radiotherapy. Lancet Oncol. 2015, 16, 1153-1186. [CrossRef]

93. Baumann, M.; Krause, M.; Hill, R. Exploring the role of cancer stem cells in radioresistance. Nat. Rev. Cancer 2008, 8, 545-554. [CrossRef]

94. Krause, M.; Yaromina, A.; Eicheler, W.; Koch, U.; Baumann, M. Cancer Stem Cells: Targets and Potential Biomarkers for Radiotherapy. Clin. Cancer Res. 2011, 17, 7224-7229. [CrossRef] [PubMed]

95. Krause, M.; Dubrovska, A.; Linge, A.; Baumann, M. Cancer stem cells: Radioresistance, prediction of radiotherapy outcome and specific targets for combined treatments. Adv. Drug Deliv. Rev. 2017, 109, 63-73. [CrossRef] [PubMed]

96. Bütof, R.; Dubrovska, A.; Baumann, M. Clinical perspectives of cancer stem cell research in radiation oncology. Radiother. Oncol. 2013, 108, 388-396. [CrossRef] [PubMed]

97. Morgan, M.A.; Lawrence, T.S. Molecular Pathways: Overcoming Radiation Resistance by Targeting DNA Damage Response Pathways. Clin. Cancer Res. 2015, 21, 2898-2904. [CrossRef] [PubMed]

98. Baumann, M.; Krause, M.; Overgaard, J.; Debus, J.; Bentzen, S.M.; Daartz, J.; Richter, C.; Zips, D.; Bortfeld, T. Radiation oncology in the era of precision medicine. Nat. Rev. Cancer 2016, 16, 234-249. [CrossRef] [PubMed]

99. Hill, R.; Lee, P.W. The DNA-dependent protein kinase (DNA-PK): More than just a case of making ends meet? Cell Cycle 2010, 9 , 3460-3469. [CrossRef] [PubMed]

100. Falck, J.; Coates, J.; Jackson, S.P. Conserved modes of recruitment of ATM, ATR and DNA-PKcs to sites of DNA damage. Nature 2005, 434, 605-611. [CrossRef] 
101. Cortez, D.; Guntuku, S.; Qin, J.; Elledge, S.J. ATR and ATRIP: Partners in Checkpoint Signaling. Science 2001, $294,1713-1716$. [CrossRef]

102. Jazayeri, A.; Falck, J.; Lukas, C.; Bartek, J.; Smith, G.C.M.; Lukas, J.; Jackson, S.P. ATM- and cell cycle-dependent regulation of ATR in response to DNA double-strand breaks. Nat. Cell Biol. 2006, 8, 37-45. [CrossRef] [PubMed]

103. Burma, S.; Chen, B.P.; Murphy, M.; Kurimasa, A.; Chen, D.J. ATM Phosphorylates Histone H2AX in Response to DNA Doublestrand Breaks. J. Biol. Chem. 2001, 276, 42462-42467. [CrossRef]

104. Ammazzalorso, F.; Pirzio, L.M.; Bignami, M.; Franchitto, A.; Pichierri, P. ATR and ATM differently regulate WRN to prevent DSBs at stalled replication forks and promote replication fork recovery. EMBO J. 2010, 29, 3156-3169. [CrossRef]

105. Johnson, N.; Cai, D.; Kennedy, R.D.; Pathania, S.; Arora, M.; Li, Y.-C.; D'Andrea, A.D.; Parvin, J.D.; Shapiro, G.I. Cdk1 Participates in BRCA1-Dependent S Phase Checkpoint Control in Response to DNA Damage. Mol. Cell 2009, 35, 327-339. [CrossRef]

106. Liu, Q.; Guntuku, S.; Cui, X.-S.; Matsuoka, S.; Cortez, D.; Tamai, K.; Luo, G.; Carattini-Rivera, S.; DeMayo, F.; Bradley, A.; et al. Chk1 is an essential kinase that is regulated by Atr and required for the G2/M DNA damage checkpoint. Genes Dev. 2000, 14, 1448-1459.

107. Matsuoka, S.; Rotman, G.; Ogawa, A.; Shiloh, Y.; Tamai, K.; Elledge, S.J. Ataxia telangiectasia-mutated phosphorylates Chk2 in vivo and in vitro. Proc. Natl. Acad. Sci. USA 2000, 97, 10389-10394. [CrossRef]

108. Khosravi, R.; Maya, R.; Gottlieb, T.; Oren, M.; Shiloh, Y.; Shkedy, D. Rapid ATM-dependent phosphorylation of MDM2 precedes p53 accumulation in response to DNA damage. Proc. Natl. Acad. Sci. USA 1999, 96, 14973-14977. [CrossRef] [PubMed]

109. Sanchez, Y.; Wong, C.; Thoma, R.S.; Richman, R.; Wu, Z.; Piwnica-Worms, H.; Elledge, S.J. Conservation of the Chk1 Checkpoint Pathway in Mammals: Linkage of DNA Damage to Cdk Regulation through Cdc25. Science 1997, 277, 1497-1501. [CrossRef]

110. Xiao, Z.; Chen, Z.; Gunasekera, A.H.; Sowin, T.J.; Rosenberg, S.H.; Fesik, S.; Zhang, H. Chk1 Mediates S and G2 Arrests through Cdc25A Degradation in Response to DNA-damaging Agents. J. Biol. Chem. 2003, 278, 21767-21773. [CrossRef] [PubMed]

111. Sorensen, C.; Syljuåsen, R.G.; Falck, J.; Schroeder, T.; Rönnstrand, L.; Khanna, K.K.; Zhou, B.-B.; Bartek, J.; Lukas, J. Chk1 regulates the $\mathrm{S}$ phase checkpoint by coupling the physiological turnover and ionizing radiation-induced accelerated proteolysis of Cdc25A. Cancer Cell 2003, 3, 247-258. [CrossRef]

112. Syljuåsen, R.G.; Sorensen, C.; Hansen, L.T.; Fugger, K.; Lundin, C.; Johansson, F.; Helleday, T.; Sehested, M.; Lukas, J.; Bartek, J. Inhibition of Human Chk1 Causes Increased Initiation of DNA Replication, Phosphorylation of ATR Targets, and DNA Breakage. Mol. Cell. Biol. 2005, 25, 3553-3562. [CrossRef] [PubMed]

113. Sorensen, C.; Hansen, L.T.; Dziegielewski, J.; Syljuåsen, R.G.; Lundin, C.; Bartek, J.; Helleday, T. The cell-cycle checkpoint kinase Chk1 is required for mammalian homologous recombination repair. Nat. Cell Biol. 2005, 7, 195-201. [CrossRef] [PubMed]

114. Zachos, G.; Black, E.J.; Walker, M.; Scott, M.; Vagnarelli, P.; Earnshaw, W.; Gillespie, D.A. Chk1 Is Required for Spindle Checkpoint Function. Dev. Cell 2007, 12, 247-260. [CrossRef]

115. Carrassa, L.; Sanchez, Y.; Erba, E.; Damia, G. U2OS cells lacking Chk1 undergo aberrant mitosis and fail to activate the spindle checkpoint. J. Cell. Mol. Med. 2009, 13, 1565-1576. [CrossRef]

116. Chilà, R.; Celenza, C.; Lupi, M.; Damia, G.; Carrassa, L. Chk1-Mad2 interaction: A crosslink between the DNA damage checkpoint and the mitotic spindle checkpoint. Cell Cycle 2013, 12, 1083-1090. [CrossRef]

117. Jette, N.; Lees-Miller, S.P. The DNA-dependent protein kinase: A multifunctional protein kinase with roles in DNA double strand break repair and mitosis. Prog. Biophys. Mol. Biol. 2015, 117, 194-205. [CrossRef]

118. Hill, R.; Milas, L. The proportion of stem cells in murine tumors. Int. J. Radiat. Oncol. 1989, 16, 513-518. [CrossRef]

119. Baumann, M.; Dubois, W.; Suit, H.D. Response of Human Squamous Cell Carcinoma Xenografts of Different Sizes to Irradiation: Relationship of Clonogenic Cells, Cellular Radiation Sensitivity in Vivo, and Tumor Rescuing Units. Radiat. Res. 1990, 123, 325-330. [CrossRef]

120. Koch, U.; Krause, M.; Baumann, M. Cancer stem cells at the crossroads of current cancer therapy failures-Radiation oncology perspective. Semin. Cancer Biol. 2010, 20, 116-124. [CrossRef]

121. Puglisi, C.; Giuffrida, R.; Borzì, G.; Di Mattia, P.; Costa, A.; Colarossi, C.; Deiana, E.; Picardo, M.C.; Colarossi, L.; Mare, M.; et al. Radiosensitivity of Cancer Stem Cells Has Potential Predictive Value for Individual Responses to Radiotherapy in Locally Advanced Rectal Cancer. Cancers 2020, 12, 3672. [CrossRef]

122. Yaromina, A.; Krause, M.; Thames, H.; Rosner, A.; Krause, M.; Hessel, F.; Grenman, R.; Zips, D.; Baumann, M. Pre-treatment number of clonogenic cells and their radiosensitivity are major determinants of local tumour control after fractionated irradiation. Radiother. Oncol. 2007, 83, 304-310. [CrossRef] [PubMed]

123. Maugeri-Saccà, M.; Bartucci, M.; De Maria, R. DNA Damage Repair Pathways in Cancer Stem Cells. Mol. Cancer Ther. 2012, 11, 1627-1636. [CrossRef]

124. Chang, C.-H.; Zhang, M.; Rajapakshe, K.; Coarfa, C.; Edwards, D.; Huang, S.; Rosen, J.M. Mammary Stem Cells and TumorInitiating Cells Are More Resistant to Apoptosis and Exhibit Increased DNA Repair Activity in Response to DNA Damage. Stem Cell Rep. 2015, 5, 378-391. [CrossRef]

125. Wilson, W.R.; Hay, M.P. Targeting hypoxia in cancer therapy. Nat. Rev. Cancer 2011, 11, 393-410. [CrossRef]

126. Hu, C.-J.; Wang, L.-Y.; Chodosh, L.A.; Keith, B.; Simon, M.C. Differential Roles of Hypoxia-Inducible Factor $1 \alpha($ HIF- $1 \alpha)$ and HIF-2 $\alpha$ in Hypoxic Gene Regulation. Mol. Cell. Biol. 2003, 23, 9361-9374. [CrossRef]

127. Covello, K.L.; Kehler, J.; Yu, H.; Gordan, J.D.; Arsham, A.M.; Hu, C.-J.; Labosky, P.; Simon, M.C.; Keith, B. HIF-2 regulates Oct-4: Effects of hypoxia on stem cell function, embryonic development, and tumor growth. Genes Dev. 2006, 20, 557-570. [CrossRef] 
128. Gordan, J.D.; Bertout, J.A.; Hu, C.-J.; Diehl, J.A.; Simon, M.C. HIF-2 $\alpha$ Promotes Hypoxic Cell Proliferation by Enhancing c-Myc Transcriptional Activity. Cancer Cell 2007, 11, 335-347. [CrossRef] [PubMed]

129. Cordes, N.; Seidler, J.; Durzok, R.; Geinitz, H.; Brakebusch, C. $\beta 1$-integrin-mediated signaling essentially contributes to cell survival after radiation-induced genotoxic injury. Oncogene 2006, 25, 1378-1390. [CrossRef] [PubMed]

130. Bao, S.; Wu, Q.; McLendon, R.E.; Hao, Y.; Shi, Q.; Hjelmeland, A.B.; Dewhirst, M.W.; Bigner, D.D.; Rich, J.N. Glioma stem cells promote radioresistance by preferential activation of the DNA damage response. Nature 2006, 444, 756-760. [CrossRef]

131. Sarcar, B.; Kahali, S.; Prabhu, A.H.; Shumway, S.D.; Xu, Y.; DeMuth, T.; Chinnaiyan, P. Targeting Radiation-Induced G2 Checkpoint Activation with the Wee-1 Inhibitor MK-1775 in Glioblastoma Cell Lines. Mol. Cancer Ther. 2011, 10, 2405-2414. [CrossRef]

132. Ronco, C.; Martin, A.R.; Demange, L.; Benhida, R. ATM, ATR, CHK1, CHK2 and WEE1 inhibitors in cancer and cancer stem cells. MedChemComm 2017, 8, 295-319. [CrossRef] [PubMed]

133. Matheson, C.J.; Venkataraman, S.; Amani, V.; Harris, P.S.; Backos, D.; Donson, A.M.; Wempe, M.F.; Foreman, N.; Vibhakar, R.; Reigan, P. A WEE1 Inhibitor Analog of AZD1775 Maintains Synergy with Cisplatin and Demonstrates Reduced Single-Agent Cytotoxicity in Medulloblastoma Cells. ACS Chem. Biol. 2016, 11, 921-930. [CrossRef] [PubMed]

134. Matheson, C.J.; Casalvieri, K.A.; Backos, D.S.; Reigan, P. Development of Potent Pyrazolopyrimidinone-Based WEE1 Inhibitors with Limited Single-Agent Cytotoxicity for Cancer Therapy. ChemMedChem 2018, 13, 1681-1694. [CrossRef]

135. Du, X.; Li, J.; Luo, X.; Li, R.; Li, F.; Zhang, Y.; Shi, J.; He, J. Structure-activity relationships of Wee1 inhibitors: A review. Eur. J. Med. Chem. 2020, 203, 112524. [CrossRef]

136. Hashimoto, O.; Shinkawa, M.; Torimura, T.; Nakamura, T.; Selvendiran, K.; Sakamoto, M.; Koga, H.; Ueno, T.; Sata, M. Cell cycle regulation by the Wee1 Inhibitor PD0166285, Pyrido [2,3-d] pyimidine, in the B16 mouse melanoma cell line. BMC Cancer 2006, 6, 292. [CrossRef]

137. Hashimoto, O.; Ueno, T.; Kimura, R.; Ohtsubo, M.; Nakamura, T.; Koga, H.; Torimura, T.; Uchida, S.; Yamashita, K.; Sata, M. Inhibition of proteasome-dependent degradation of Wee1 in G2-arrested Hep3B cells by TGFß1. Mol. Carcinog. 2003, 36, 171-182. [CrossRef]

138. Panek, R.L.; Lu, G.H.; Klutchko, S.R.; Batley, B.L.; Dahring, T.K.; Hamby, J.M.; Hallak, H.; Doherty, A.M.; Keiser, J.A. In vitro pharmacological characterization of PD 166285, a new nanomolar potent and broadly active protein tyrosine kinase inhibitor. $J$. Pharmacol. Exp. Ther. 1997, 283, 1433-1444.

139. Palmer, B.D.; Smaill, J.B.; Rewcastle, G.W.; Dobrusin, E.M.; Kraker, A.; Moore, C.W.; Steinkampf, R.W.; Denny, W.A. Structureactivity relationships for 2-anilino-6-phenylpyrido[2,3- $d$ ]pyrimidin-7(8H)-ones as inhibitors of the cellular checkpoint kinase Wee1. Bioorgan. Med. Chem. Lett. 2005, 15, 1931-1935. [CrossRef] [PubMed]

140. Hamby, J.M.; Connolly, C.J.C.; Schroeder, M.C.; Winters, R.T.; Showalter, H.D.H.; Panek, R.L.; Major, T.C.; Olsewski, B.; Ryan, M.J.; Dahring, T.; et al. Structure-Activity Relationships for a Novel Series of Pyrido[2,3- $d$ ]pyrimidine Tyrosine Kinase Inhibitors. J. Med. Chem. 1997, 40, 2296-2303. [CrossRef]

141. Thompson, A.M.; Connolly, C.J.C.; Hamby, J.M.; Boushelle, S.; Hartl, B.G.; Amar, A.M.; Kraker, A.J.; Driscoll, D.L.; Steinkampf, R.W.; Patmore, S.J.; et al. 3-(3,5-Dimethoxyphenyl)-1,6-naphthyridine-2,7-diamines and Related 2-Urea Derivatives Are Potent and Selective Inhibitors of the FGF Receptor-1 Tyrosine Kinase. J. Med. Chem. 2000, 43, 4200-4211. [CrossRef] [PubMed]

142. Hirai, H.; Iwasawa, Y.; Okada, M.; Arai, T.; Nishibata, T.; Kobayashi, M.; Kimura, T.; Kaneko, N.; Ohtani, J.; Yamanaka, K.; et al. Small-molecule inhibition of Wee1 kinase by MK-1775 selectively sensitizes p53-deficient tumor cells to DNA-damaging agents. Mol. Cancer Ther. 2009, 8, 2992-3000. [CrossRef] [PubMed]

143. Palmer, B.D.; Thompson, A.M.; Booth, R.J.; Dobrusin, E.M.; Kraker, A.J.; Lee, H.H.; Lunney, E.A.; Mitchell, L.H.; Ortwine, D.F.; Smaill, J.B.; et al. 4-Phenylpyrrolo[3,4-c]carbazole-1,3(2H,6H)-dione Inhibitors of the Checkpoint Kinase Wee1. Structure-Activity Relationships for Chromophore Modification and Phenyl Ring Substitution. J. Med. Chem. 2006, 49, 4896-4911. [CrossRef] [PubMed]

144. Arora, S.; Bisanz, K.M.; Peralta, L.A.; Basu, G.D.; Choudhary, A.; Tibes, R.; Azorsa, D.O. RNAi screening of the kinome identifies modulators of cisplatin response in ovarian cancer cells. Gynecol. Oncol. 2010, 118, 220-227. [CrossRef]

145. Smaill, J.B.; Baker, E.N.; Booth, R.J.; Bridges, A.J.; Dickson, J.M.; Dobrusin, E.M.; Ivanovic, I.; Kraker, A.J.; Lee, H.H.; Lunney, E.A.; et al. Synthesis and structure-activity relationships of N-6 substituted analogues of 9-hydroxy-4-phenylpyrrolo[3,4-c]carbazole1,3(2H,6H)-diones as inhibitors of Wee1 and Chk1 checkpoint kinases. Eur. J. Med. Chem. 2008, 43, 1276-1296. [CrossRef]

146. Smaill, J.B.; Lee, H.H.; Palmer, B.D.; Thompson, A.M.; Squire, C.J.; Baker, E.N.; Booth, R.J.; Kraker, A.; Hook, K.; Denny, W.A. Synthesis and structure-activity relationships of soluble 8-substituted 4-(2-chlorophenyl)-9-hydroxypyrrolo[3,4-c]carbazole1,3(2H,6H)-diones as inhibitors of the Wee1 and Chk1 checkpoint kinases. Bioorgan. Med. Chem. Lett. 2008, 18, 929-933. [CrossRef]

147. Tong, Y.; Torrent, M.; Florjancic, A.S.; Bromberg, K.D.; Buchanan, F.G.; Ferguson, D.C.; Johnson, E.F.; Lasko, L.M.; Maag, D.; Merta, P.J.; et al. Pyrimidine-Based Tricyclic Molecules as Potent and Orally Efficacious Inhibitors of Wee1 Kinase. ACS Med. Chem. Lett. 2014, 6, 58-62. [CrossRef] [PubMed]

148. Khan, N.; Afaq, F.; Saleem, M.; Ahmad, N.; Mukhtar, H. Targeting Multiple Signaling Pathways by Green Tea Polyphenol (-)-Epigallocatechin-3-Gallate. Cancer Res. 2006, 66, 2500-2505. [CrossRef]

149. Banerjee, S.; Li, Y.; Wang, Z.; Sarkar, F.H. Multi-targeted therapy of cancer by genistein. Cancer Lett. 2008, 269, 226-242. [CrossRef] [PubMed] 
150. Ravindran, J.; Prasad, S.; Aggarwal, B.B. Curcumin and Cancer Cells: How Many Ways Can Curry Kill Tumor Cells Selectively? AAPS J. 2009, 11, 495-510. [CrossRef]

151. Cuccioloni, M.; Mozzicafreddo, M.; Bonfili, L.; Cecarini, V.; Eleuteri, A.M.; Angeletti, M. Natural Occurring Polyphenols as Template for Drug Design. Focus on Serine Proteases. Chem. Biol. Drug Des. 2009, 74, 1-15. [CrossRef] [PubMed]

152. Korkina, L.; De Luca, C.; Kostyuk, V.; Pastore, S. Plant Polyphenols and Tumors: From Mechanisms to Therapies, Prevention, and Protection Against Toxicity of Anti-Cancer Treatments. Curr. Med. Chem. 2009, 16, 3943-3965. [CrossRef] [PubMed]

153. Lamoral-Theys, D.; Pottier, L.; Dufrasne, F.; Neve, J.; Dubois, J.; Kornienko, A.; Kiss, R.; Ingrassia, L. Natural Polyphenols that Display Anticancer Properties through Inhibition of Kinase Activity. Curr. Med. Chem. 2010, 17, 812-825. [CrossRef] [PubMed]

154. Reuter, S.; Eifes, S.; Dicato, M.; Aggarwal, B.B.; Diederich, M. Modulation of anti-apoptotic and survival pathways by curcumin as a strategy to induce apoptosis in cancer cells. Biochem. Pharmacol. 2008, 76, 1340-1351. [CrossRef] [PubMed]

155. Yang, C.S.; Wang, X.; Lu, G.; Picinich, S.C. Cancer prevention by tea: Animal studies, molecular mechanisms and human relevance. Nat. Rev. Cancer 2009, 9, 429-439. [CrossRef]

156. Lamoral-Theys, D.; Pottier, L.; Kerff, F.; Dufrasne, F.; Proutiere, F.; Wauthoz, N.; Neven, P.; Ingrassia, L.; Van Antwerpen, P.; Lefranc, F.; et al. Simple di- and trivanillates exhibit cytostatic properties toward cancer cells resistant to pro-apoptotic stimuli. Bioorgan. Med. Chem. 2010, 18, 3823-3833. [CrossRef]

157. Bridges, K.A.; Hirai, H.; Buser, C.A.; Brooks, C.; Liu, H.; Buchholz, T.; Molkentine, J.; Mason, K.A.; Meyn, R.E. MK-1775, a Novel Wee1 Kinase Inhibitor, Radiosensitizes p53-Defective Human Tumor Cells. Clin. Cancer Res. 2011, 17, 5638-5648. [CrossRef]

158. Do, K.; Doroshow, J.H.; Kummar, S. Wee1 kinase as a target for cancer therapy. Cell Cycle 2013, 12, 3348-3353. [CrossRef]

159. Osman, A.A.; Monroe, M.M.; Alves, M.V.O.; Patel, A.A.; Katsonis, P.; Fitzgerald, A.L.; Neskey, D.M.; Frederick, M.J.; Woo, S.H.; Caulin, C.; et al. Wee-1 Kinase Inhibition Overcomes Cisplatin Resistance Associated with High-Risk TP53 Mutations in Head and Neck Cancer through Mitotic Arrest Followed by Senescence. Mol. Cancer Ther. 2015, 14, 608-619. [CrossRef]

160. Caretti, V.; Hiddingh, L.; Lagerweij, T.; Schellen, P.; Koken, P.W.; Hulleman, E.; van Vuurden, D.G.; Vandertop, W.P.; Kaspers, G.J.; Noske, D.P.; et al. WEE1 Kinase Inhibition Enhances the Radiation Response of Diffuse Intrinsic Pontine Gliomas. Mol. Cancer Ther. 2013, 12, 141-150. [CrossRef]

161. Karnak, D.; Engelke, C.G.; Parsels, L.A.; Kausar, T.; Wei, D.; Robertson, J.R.; Marsh, K.B.; Davis, M.A.; Zhao, L.; Maybaum, J.; et al. Combined inhibition of Wee1 and PARP1/2 for radiosensitization in pancreatic cancer. Clin. Cancer Res. 2014, 20, 5085-5096. [CrossRef] [PubMed] 